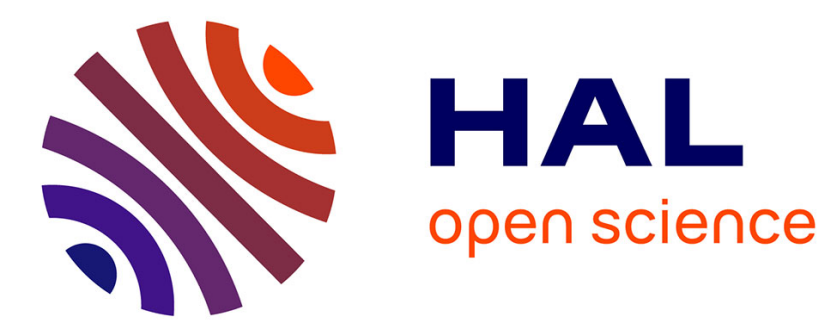

\title{
Dissolved trace metals (Ni, Zn, Co, Cd, Pb, Al, and Mn) around the Crozet Islands, Southern Ocean
}

Maxi Castrillejo, Peter J. Statham, Gary R. Fones, Hélène Planquette, Farah

Idrus, Keiron Roberts

\section{- To cite this version:}

Maxi Castrillejo, Peter J. Statham, Gary R. Fones, Hélène Planquette, Farah Idrus, et al.. Dissolved trace metals (Ni, Zn, $\mathrm{Co}, \mathrm{Cd}, \mathrm{Pb}, \mathrm{Al}$, and $\mathrm{Mn}$ ) around the Crozet Islands, Southern Ocean. Journal of Geophysical Research. Oceans, 2013, 118, pp.5188-5201. 10.1002/JGRC.20359 . hal-00939263

\section{HAL Id: hal-00939263 \\ https://hal.univ-brest.fr/hal-00939263}

Submitted on 30 Jul 2014

HAL is a multi-disciplinary open access archive for the deposit and dissemination of scientific research documents, whether they are published or not. The documents may come from teaching and research institutions in France or abroad, or from public or private research centers.
L'archive ouverte pluridisciplinaire HAL, est destinée au dépôt et à la diffusion de documents scientifiques de niveau recherche, publiés ou non, émanant des établissements d'enseignement et de recherche français ou étrangers, des laboratoires publics ou privés. 


\title{
Dissolved trace metals ( $\mathrm{Ni}, \mathrm{Zn}, \mathrm{Co}, \mathrm{Cd}, \mathrm{Pb}, \mathrm{Al}$, and $\mathrm{Mn})$ around the Crozet Islands, Southern Ocean
}

\author{
Maxi Castrillejo, ${ }^{1,2}$ Peter J. Statham, ${ }^{1}$ Gary R. Fones, ${ }^{3}$ Hélène Planquette, ${ }^{4}$ Farah Idrus,,${ }^{1,5}$ \\ and Keiron Roberts ${ }^{1}$
}

Received 13 December 2012; revised 23 July 2013; accepted 9 August 2013; published 9 October 2013.

[1] A phytoplankton bloom shown to be naturally iron (Fe) induced occurs north of the Crozet Islands (Southern Ocean) every year, providing an ideal opportunity to study dissolved trace metal distributions within an island system located in a high nutrient low chlorophyll (HNLC) region. We present water column profiles of dissolved nickel (Ni), zinc $(\mathrm{Zn})$, cobalt $(\mathrm{Co})$, cadmium $(\mathrm{Cd})$, lead $(\mathrm{Pb})$, aluminium $(\mathrm{Al})$, and manganese $(\mathrm{Mn})$ obtained as part of the NERC CROZEX program during austral summer (2004-2005). Two stations (M3 and M1) were sampled downstream (north) of Crozet in the bloom area and near the islands, along with a control station (M2) in the HNLC zone upstream (south) of the islands. The general range found was for Ni, 4.64-6.31 nM; Zn, 1.59-7.75 nM; Co, 24-49 pM; Cd, 135-673 pM; Pb, 6-22 pM; Al, 0.13-2.15 nM; and Mn, 0.07-0.64 nM. Vertical profiles indicate little island influence to the south with values in the range of other trace metal deprived regions of the Southern Ocean. Significant removal of Ni and Cd was observed in the bloom and $\mathrm{Zn}$ was moderately correlated with reactive silicate $(\mathrm{Si})$ indicating diatom control over the internal cycling of this metal. Higher concentrations of $\mathrm{Zn}$ and $\mathrm{Cd}$ were observed near the islands. $\mathrm{Pb}, \mathrm{Al}$, and $\mathrm{Mn}$ distributions also suggest small but significant atmospheric dust supply particularly in the northern region.

Citation: Castrillejo, M., P. J. Statham, G. R. Fones, H. Planquette, F. Idrus, and K. Roberts (2013), Dissolved trace metals (Ni, Zn, $\mathrm{Co}, \mathrm{Cd}, \mathrm{Pb}, \mathrm{Al}$, and Mn) around the Crozet Islands, Southern Ocean, J. Geophys. Res. Oceans, 118, 5188-5201, doi:10.1002/jgrc.20359.

\section{Introduction}

[2] Artificial $\mathrm{Fe}$ enrichment experiments (summarized by Boyd et al. [2007] and de Baar et al. [2005]) confirmed $\mathrm{Fe}$ as the prime limiting micronutrient in HNLC regions. A range of other bioactive trace metals are also vital for biological productivity as they are often involved in enzymatic activity or become part of proteins [Morel and Price, 2003]. Some trace metals may be colimiting [Morel et al., 1994] when at low concentrations or toxic at elevated concentrations [Mann et al., 2002] and the bioavailability of trace elements such as $\mathrm{Zn}, \mathrm{Co}$, and $\mathrm{Cd}$ may be influenced

\footnotetext{
Additional supporting information may be found in the online version of this article.

${ }^{1}$ National Oceanography Centre of Southampton, University of Southampton, Southampton, UK.

${ }^{2}$ Institut de Ciència i Tecnologia Ambientals, Universitat Autònoma de Barcelona, Bellaterra, Spain.

${ }^{3}$ School of Earth and Environment Sciences, , University of Portsmouth, Portsmouth, UK.

${ }^{4}$ Laboratoire des Sciences de 1'Environnement Marin, Institut Universitaire Européen de la Mer, Plouzané France.

${ }^{5}$ Faculty of Resources Science and Technology, Department of Aquatic Science, University Malaysia Sarawak, Sarawak, Malaysia.

Corresponding author: M. Castrillejo, National Oceanography Centre of Southampton, University of Southampton, Waterfront Campus, European Way, Southampton SO14 3ZH, UK. (mcastrillejo.sci@gmail.com)

(C) 2013. American Geophysical Union. All Rights Reserved. 2169-9275/13/10.1002/jgrc.20359
}

by complexing ligands [e.g., Zn: Bruland, 1989; Ellwood and van den Berg, 2000; Co: Ellwood and van den Berg, 2001; Saito et al., 2004; Cd: Bruland, 1992].

[3] The Southern Ocean is the largest HNLC region and plays a key role in climate regulation via the ocean carbon pump [Anderson et al., 2009]. It is typically characterized by biolimiting concentrations of $\mathrm{Fe}$, deep mixed layers in winter, with moderate seasonal warming and stratification. Therefore, this region can be very sensitive to climate change due to an increased stratification [Sarmiento et al., 1998] which may affect the biological pump and the water mass formation and circulation [Marinov et al., 2006; De Vries and Primeau, 2011]. However, studies of trace metals other than Fe are limited and only few of them cover the deep waters of the Southern Ocean [Aparicio-Gonzalez et al., 2012]. Data for the Indian sector of the Southern Ocean including the metals investigated here are particularly scarce. van Beusekom et al. [1997] provided the first water column and sedimentary distribution of $\mathrm{Al}$ and silicic acid along the Enderby and Crozet Basins. Bucciarelli et al. [2001] found coastal and offshore waters enriched in dissolved $\mathrm{Mn}$ and Fe with sedimentary and lithogenic origin in the wake of Kerguelen Islands, whereas Bown et al. [2012] suggested that lateral advection and dissolution of Co from basaltic sediments explain the high dissolved Co concentrations above the Kerguelen Plateau.

[4] The interdisciplinary CROZet natural iron bloom and EXport experiment (CROZEX) [Pollard et al., 2007b] confirmed that Fe released from the Crozet Islands and Plateau 
[Planquette et al., 2007] supports an annual bloom and leads to an increase of the C export [Pollard et al., 2009]. Large-scale circulation constrains the bloom to the north of the Islands [Pollard et al., 2007a] providing an ideal location to compare the trace metal behavior of the naturally induced bloom with HNLC conditions south of the archipelago. This is the first reporting of trace metal concentrations in this area to date with the exception of dissolved $\mathrm{Fe}$ [Planquette et al., 2007] and particulate $\mathrm{Fe}$ and $\mathrm{Al}$ [Planquette et al., 2009].

[5] This study provides vertical distributions of dissolved $\mathrm{Ni}, \mathrm{Zn}, \mathrm{Co}, \mathrm{Cd}, \mathrm{Pb}, \mathrm{Al}$, and $\mathrm{Mn}$, constituting a substantial addition to the trace metal biogeochemistry knowledge around Crozet Islands and more generally, in a Southern Ocean naturally induced bloom. Results are discussed in terms of sources, sinks, and biogeochemical cycles in order to test the hypotheses that (1) trace element concentrations south of the archipelago are representative of other HNLC zones within the Southern Ocean and (2) bioactive trace metals show biological uptake in the bloom area.

\section{Methods}

\subsection{Study Area, the Phytoplankton Bloom, and Sampling Sites}

[6] Crozet $\left(46^{\circ} \mathrm{S}, 52^{\circ} \mathrm{E}\right)$ is located in the western Indian Sector of the Southern Ocean, $2500 \mathrm{~km}$ southeast of South Africa. It comprises a shallow plateau, two main islands, "Île de la Possession" and "Île de l'Est," as well as three smaller ones $100 \mathrm{~km}$ further west (Figure 1).

[7] Lying within the Polar Frontal Zone (PFZ) [Pollard et al., 2002], Crozet is bounded west and north by an "S"shaped Sub-Antarctic Front (SAF), the northern branch of the Antarctic Circumpolar Current (ACC) and south by the Polar Front (PF) [Pollard et al., 2007a], a permanent feature mainly controlled by the topography of Del Caño Rise and Crozet Plateau [Pollard and Read, 2001]. The accumulation of $\mathrm{Fe}$ and development of the bloom to the north is facilitated by the long residence time ( $\sim 62$ days) of water in the SAF semienclosed area and the weak northward surface flow passing over the Crozet Plateau [Pollard et al., 2007a]. Therefore, south of Crozet can be referred to as "upstream," while north of Crozet is "downstream" of the islands. A complete description of the circulation around Crozet is given by Pollard et al. [2007a].

[8] The bloom starts north of the plateau then moves south toward the islands. The beginning and initial location of the bloom are controlled by the gradual increase of light during austral spring and summer, whereas its development is dominated by physical conditions and micro and macronutrient availability [Venables and Moore, 2010; Venables et al., 2007]. Venables et al. [2007] showed using merged Sea WIFS/MODIS Chl- $a$ images that the main bloom began north of the plateau in early-mid September 2004 and followed an exponential-like growth up to mean chlorophyll concentrations of $\sim 4 \mu \mathrm{g}$ Chl- $a \mathrm{~L}^{-1}$ before collapsing by early November 2004.

[9] The samples analyzed here were taken during the first cruise (D285) of the CROZEX project on board of RRS Discovery, from 3 November to 10 December 2004, right after the main bloom declined [Venables et al., 2007].

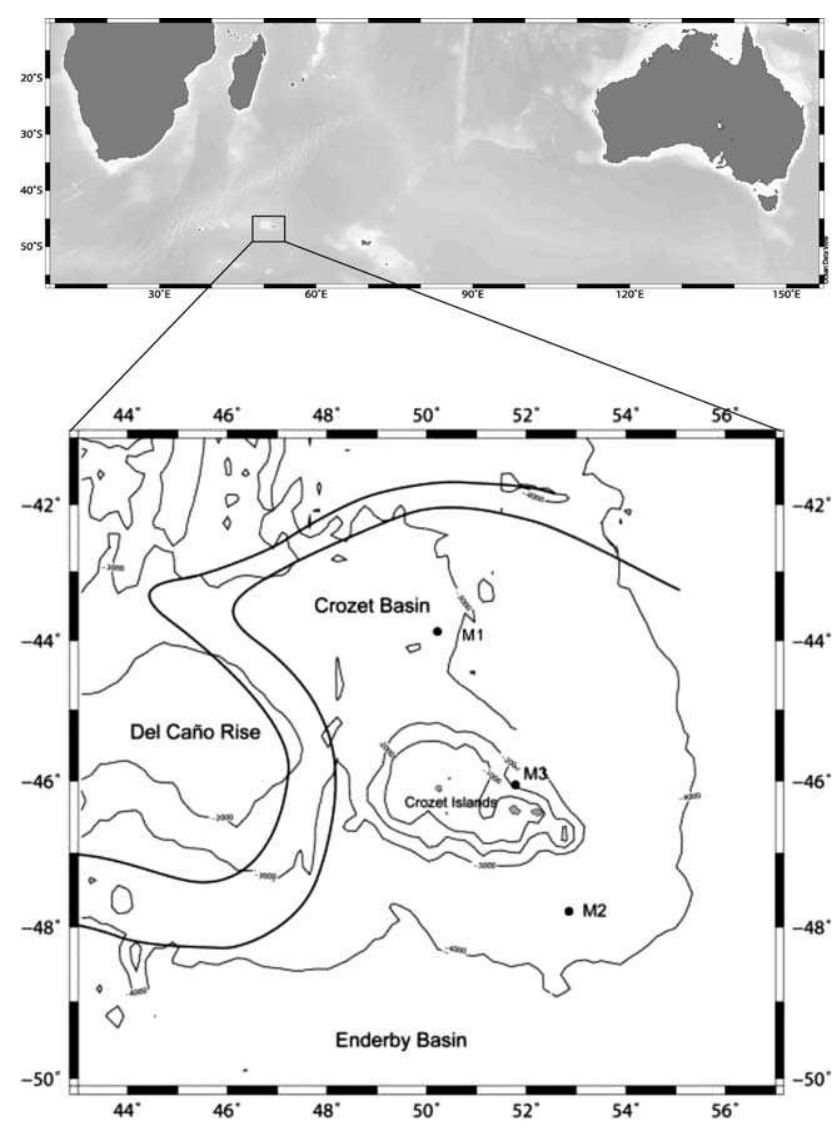

Figure 1. Bathymetry of the survey area between 40 and $50^{\circ} \mathrm{S}$ and 43 and $57^{\circ} \mathrm{E}$. Black filled circles mark sites M1, M2, and M3 sampled during leg 1 (D285) of CROZEX experiment (courtesy of Raymond Pollard, NOCS). The sub-Antarctic Front (SAF) is indicated by the thin black lines. Detailed information about sampling sites and circulation can be found in Pollard et al. [2007a, 2007b].

The three stations included in this study were located at sites M1 (bloom area), M3 (island vicinity), and M2 (HNLC area), respectively (Figure 1). Detailed information about sampling sites is given by Pollard et al. [2007b].

\subsection{Sampling and Cleaning Procedures}

\subsubsection{Inorganic Nutrients}

[10] In summary, samples were collected using a tracemetal clean Titaniun conductivity-temperature-depth (CTD) rosette, directly transferred from Niskin bottles to polystyrene coulter counter vials and stored at $4^{\circ} \mathrm{C}$ for $12 \mathrm{~h}$ prior to analysis. A Skalar San ${ }^{\text {plus }}$ autoanalyzer was used to determine nitrate + nitrite (hereinafter nitrate), phosphate, and reactive silica (hereinafter $\mathrm{Si}$ ) following Sanders and Jickells [2000]. Details on analysis and data quality for the inorganic nutrients can be found in Sanders et al. [2007]. Since no nutrient data for station M2 were available, we use data from nearest stations $(<80 \mathrm{~km}$, stations 500 and 506, Sanders et al. [2007]) that were sampled $6 \mathrm{~h}$ before and $17 \mathrm{~h}$ after M2 using a stainless CTD rosette.

\subsubsection{Trace Metals}

[11] Prior to the cruise, low-density polyethylene (LDPE) storage bottles (500 and $1000 \mathrm{~mL}$ ) were soaked for 3 days each in $\sim 2 \%$ (v/v) aqueous Decon detergent and, 
$50 \%(\mathrm{v} / \mathrm{v})$ hydrochloric $(\mathrm{HCl})$, and $50 \%(\mathrm{v} / \mathrm{v})$ nitric $\left(\mathrm{HNO}_{3}\right)$ acids (Fisher Scientific, Trace Metal Grade). Bottles were rinsed with Milli-Q water $(>18.2 \mathrm{M} \Omega \mathrm{cm})$ between different steps and after the last acid bath. The bottles were filled with Milli-Q water acidified to a $\mathrm{pH}$ of $\sim 1.9$ with quartz subboiled distilled $\mathrm{HCl}(\mathrm{Q}-\mathrm{HCl})$ and stored in clean zipper seal polyethylene bags in a class-100 clean-air laboratory at room temperature. Polycarbonate filters were soaked in $10 \%(\mathrm{v} / \mathrm{v}) \mathrm{Q}-\mathrm{HCl}$ for 14 days, rinsed and stored in Milli-Q water. Seawater was collected on a trace-metal clean Titanium rosette equipped with $10 \mathrm{~L}$ Ocean Technical Equipment (OTE) bottles modified for trace metal sampling. Samples were processed on board in a container equipped with a class 100 laminar flow bench. OTE bottles were pressurized with filtered high-purity nitrogen (BOC Gases) before valves were opened. Seawater was directed through an acid-washed $0.2 \mu \mathrm{m}$ polycarbonate filter (Whatman) housed in an acid-washed Teflon filtration unit. Samples were stored in $1 \mathrm{~L}$ and 500 $\mathrm{mL}$ clean low-density polyethylene bottles (Nalgene). Bottles were rinsed twice with the seawater sample prior to storage. After collection, samples were acidified with Q$\mathrm{HCl}$ to $\mathrm{pH} \sim 1.7$ and stored prior to analysis. A full description is given by Planquette et al. [2007].

\subsection{Trace Metal Analyses}

\subsubsection{Dissolved Nickel, Zinc, Cobalt, Cadmium, and} Lead

[12] The method involves an off-line removal of the salt matrix and preconcentration of metals $(\mathrm{Ni}, \mathrm{Zn}, \mathrm{Co}, \mathrm{Cd}$, and $\mathrm{Pb}$ ) using the commercial resin Toyopearl AF-Chelate$650 \mathrm{M}$ (Tosoh Bioscience) prior to their determination by ICP-MS. This resin has been recently used for multielemental extraction of trace metals in seawater [Milne et al., 2010].

[13] LDPE bottles (Nalgene) and $125 \mathrm{~mL}$ Teflon bottles (Fluorinated Ethylene Propylene (FEP), Nalgene) were used for reagent storage and UV radiation of samples, respectively. All containers were cleaned following the cleaning steps described before and stored in double zipper seal polyethylene bags when not being used. Sample manipulation was done following clean trace metal handling techniques in a laminar flow hood.

[14] High-purity nitric, hydrochloric, and acetic acids (ROMIL SpA grade), and Milli-Q water $(>18.2 \mathrm{M} \Omega \mathrm{cm}$ ) were used for the preparation of all reagents, including $\mathrm{HNO}_{3}(1 \mathrm{M})$ eluent and $\mathrm{HCl}(2 \mathrm{M})$ column wash solutions. Saturated ammonium acetate solution (19.2 M) was obtained by adding Milli-Q water to solid ammonium acetate that had been formed by bubbling high-purity ammonia gas through cooled concentrated acetic acid and the saturated solution was then diluted with Milli-Q water to give a $2 \mathrm{M}$ buffer solution. An additional ammonium acetate buffer wash solution $(20 \mathrm{mM})$ was made by further dilution of the $2 \mathrm{M}$ reagent. The ammonium acetate $(2 \mathrm{M})$ was adjusted to the appropriate $\mathrm{pH}$ using high-purity ammonia solution such that on addition of the buffer solution to the seawater samples (initial pH 1.7) and acidified North Atlantic bulk seawater that was used as an internal reference material, a final $\mathrm{pH}$ of $\sim 5.9$ was obtained.

[15] An enclosed flow through system was built to reduce external contamination, in which six parallel micro- columns (laboratory made from polymethyl methacrylate with an internal volume of $\sim 80 \mu \mathrm{L}$ ) were filled with the chelating resin. Sample, wash, and eluting solutions were pushed through the columns with a six channel peristaltic pump (Gilson Mini-Puls) at a speed of $1.6 \mathrm{~mL} \mathrm{~min}^{-1}$. Pump tubing was made of PVC and connecting tubing was made of FEP ( $0.8 \mathrm{~mm}$ i.d).

[16] It has been reported that a significant fraction of bioactive trace metals such as $\mathrm{Zn}, \mathrm{Co}$, and $\mathrm{Cu}$ form chelates with strong metal-binding organic ligands in seawater [Bruland, 1989; Coale and Bruland, 1988; Ellwood and van den Berg, 2001]. Recent studies suggest that $\sim 40 \%$ of Co [Milne et al., 2010; Shelley et al., 2010] and $\sim 10 \%$ of $\mathrm{Cu}$ [Milne et al., 2010] remain strongly bound to organic ligands even after long periods of acidification, and these complexes may make the metals unavailable to chelating resins. To convert the complexed metals to resin available forms, samples were UV irradiated in a purpose built system containing four low power UV lamps (20W each, Ultra-Violet Products Ltd) placed either side of the water samples at a distance of $\sim 2 \mathrm{~cm}$ from the FEP bottles. Initial experiments demonstrated that irradiation for $3 \mathrm{~h}$ was required to make Co fully available to the Toyopearl resin, subsequently all Crozet samples were then irradiated for this time prior to the metal preconcentration and salt matrix removal using the column system.

[17] After UV irradiation, ammonium acetate solution (20 $\mathrm{mM}$ ) with a $\mathrm{pH} \sim 5.9$ was circulated for $1 \mathrm{~min}$ through the sample lines and columns to remove any residual acid from the previous elution step. Aliquots $(\sim 100 \mathrm{~mL})$ of the acidified samples ( $\mathrm{pH} \sim 1.7$ ) were buffered to $\mathrm{pH} \sim 5.9$ and pumped through the column system. A 1 min rinse with ammonium acetate solution $(20 \mathrm{mM})$ was then used to remove the residual salt in the columns. The exact mass of seawater passed through each column was determined gravimetrically. Metals were eluted using $2 \mathrm{~mL}$ of $\mathrm{HNO}_{3}$ (1 M) into $4 \mathrm{~mL}$ acid cleaned auto-sampler polypropylene vials. Columns were cleaned for 1 min with $\mathrm{HNO}_{3}(1 \mathrm{M})$ after sample collection to remove any residual analyte. Before and after every analytical session with the system, columns, tubing, fittings, and connectors of the manifold were cleaned using $\mathrm{HCl}(2 \mathrm{M})$ and Milli-Q water for 10 and 5 min, respectively.

[18] Measurements of metals in concentrates were performed using an Agilent 7500ce Inductively Coupled Plasma-Mass Spectrometer (ICP-MS) that uses an octopole reaction system. The reaction system was run in collision mode using helium gas for the analysis of $\mathrm{Co}^{59}, \mathrm{Ni}^{60}, \mathrm{Zn}^{66}$, $\mathrm{Cd}^{111}$, and $\mathrm{Pb}^{208}$. The use of the octopole reaction system eliminates any polyatomic spectral interference and, therefore, the need for interference corrections. For $\mathrm{Pb}$, the isotopes of $\mathrm{Pb}$ were summed using the Agilent ChemStation software. This approach helps minimize any errors caused by variations in the natural isotopic pattern which is often observed. For this work, mixed standards were prepared in the range of $0.001-50 \mu \mathrm{g} \mathrm{L}^{-1}$ in a $2 \% \mathrm{HNO}_{3} / 0.5 \% \mathrm{HCl}$ (v/v) solution. For $\mathrm{Co}^{59}, \mathrm{Cd}^{111}$, and $\mathrm{Pb}^{208}$, the calibration range was from 0.001 to $5 \mu \mathrm{g} \mathrm{L}^{-1}$, while for $\mathrm{Ni}^{60}$ and $\mathrm{Zn}^{66}$, it was from 0.01 to $50 \mu \mathrm{g} \mathrm{L}^{-1}$. The calibration standards were run at the start of the day and quality control standards of 0.1 and $1 \mu \mathrm{g} \mathrm{L}^{-1}$ were run every 20 samples to check for drift, these were then incorporated into the set of 
Table 1. Blanks $(n=5)$, Limits of Detection $(3 \sigma)$, and Column Recoveries for Ni, Zn, Co, Cd, and $\mathrm{Pb}$

\begin{tabular}{lccc}
\hline & Blank & Limit of Detection & Recovery (\%) \\
\hline $\mathrm{Ni}(\mathrm{nM})$ & $0.01-0.02$ & $0.02-0.04$ & $93-99$ \\
$\mathrm{Zn}(\mathrm{nM})$ & $0.08-0.19$ & $0.12-0.43$ & $89-93$ \\
$\mathrm{Co}(\mathrm{pM})$ & $1-3$ & $2-8$ & $91-97$ \\
$\mathrm{Cd}(\mathrm{pM})$ & $5-6$ & $2-7$ & $74-77$ \\
$\mathrm{~Pb}(\mathrm{pM})$ & $2-4$ & $2-8$ & $92-98$ \\
\hline
\end{tabular}

standards to produce new calibration curves at the end of the run. An internal standard of $20 \mu \mathrm{g} \mathrm{L}^{-1} \mathrm{Rh}^{103}$ and $\mathrm{Bi}^{209}$ (stock solution of $400 \mu \mathrm{g} \mathrm{L}^{-1} \mathrm{Rh}^{103}$ and $\mathrm{Bi}^{209}$ with 20 -fold online dilution) was used to determine any variation in the intensity of their signal; $\mathrm{Rh}^{103}$ was used to correct the $\mathrm{Co}^{59}$, $\mathrm{Ni}^{60}, \mathrm{Zn}^{66}$, and $\mathrm{Cd}^{111}$ signal while $\mathrm{Bi}^{209}$ was used for $\mathrm{Pb}^{208}$. The data processing procedure including linear drift correction, blank subtraction, calibrations, and $\mathrm{Pb}^{208}$ correction was all undertaken using the Agilent software ChemStation.

[19] Information relevant to blanks, limit of detection, and metal recovery of the preconcentration and salt matrix removal step is presented in Table 1 . The blank was calculated using Milli-Q water which was processed in the same way as samples at the beginning of every analytical day and between each batch of samples. Blank range $(n=5)$ spanned from 0.01 to $0.02 \mathrm{nM} ; 0.08$ to $0.19 \mathrm{nM} ; 1$ to 3 $\mathrm{pM}$; 5 to $6 \mathrm{pM}$; and 2 to $4 \mathrm{pM}$ for $\mathrm{Ni}, \mathrm{Zn}, \mathrm{Co}, \mathrm{Cd}$, and $\mathrm{Pb}$, respectively. Blanks were generally $1-2$ orders of magnitude lower than measured concentrations in the samples, and limits of detection calculated as three times the standard deviation of blank values $(3 \sigma)$ were well below the concentrations found in the samples. A mixed standard (2.5 $\mathrm{nM}$ for $\mathrm{Ni}$ and $\mathrm{Zn} ; 0.1 \mathrm{nM}$ for $\mathrm{Co}, \mathrm{Cd}$, and $\mathrm{Pb}$ ) was used to check the recovery of metals in each column, typically one standard every six Crozet samples. Recovery was always above $90 \%$ except for $\mathrm{Cd}$ that showed a recovery of $74 \%$. Thus, hereinafter all presented $\mathrm{Cd}$ data are corrected for the recovery. Low recoveries of $\mathrm{Cd}$ when hydrochloric acid is used for acidification during storage have been reported elsewhere and the use of nitric acid seems to be more effective at removing organic interferences ( $\mathrm{P}$. Croot, personal communication, 2013). Recoveries between columns only varied $3-6 \%$ and data were very reproducible. Duplicates were made every three Crozet samples and North Atlantic bulk seawater was used as internal standard to address any bias of the analytical method. Accuracy was determined using Certified International Standard Materials NASS-6 and CASS-5 (National Research Council of Canada) that were processed in the same way as the samples (Table 2) but without UV irradiation to ensure consistency with analyses done in generating the certified values.

\subsubsection{Dissolved Aluminium}

[20] Dissolved Al was determined using the lumogallion fluorimetric method described by Hydes and Liss [1976], that has been used extensively for studies of dissolved Al in the ocean without [van Beusekom et al., 1997] or with a preconcentration step included [Resing and Measures, 1994]. High-purity reagents were used throughout including the ammonium acetate buffer (to provide a $\mathrm{pH}$ of 5) and ammonia solution, and the fluorescent $\mathrm{Al}$ compound was allowed to form overnight at room temperature in FEP bottles. The fluorescence signal was measured using a Perkin Elmer LS55, with excitation and emission wavelengths set at 480 and $590 \mathrm{~nm}$, respectively. Procedural blank was 0.758 $\mathrm{nM}$ with a precision of $0.048 \mathrm{nM}$. The detection limit (calculated as three times the standard deviation of the blank) was $0.143 \mathrm{nM}$, and averaged relative standard deviation (based on measurements of one sample) was $2.6 \%$. The certified reference materials (CRM) used did not have certified values for $\mathrm{Al}$, and the SAFe samples were not available at the time of analysis. However, the generally good agreement between data here and earlier measurement of $\mathrm{Al}$ in nearby waters supports the accuracy of the method.

\subsubsection{Dissolved Manganese}

[21] Dissolved Mn was determined using a luminol chemiluminescent technique based on the methods described by Doi et al. [2004], in which Mn is initially preconcentrated on Toyopearl $650 \mathrm{AF}$ resin, prior to elution and separation from potentially interfering metal ions using an 8-hydroxyquinoline resin and determination using the luminol light-emitting reaction. Samples were individually buffered prior to analysis. Procedural blank was $40 \mathrm{pM}$ with a precision of $20 \mathrm{pM}$. The detection limit (calculated as three times the standard deviation of the blank) was $60 \mathrm{pM}$ with an average relative standard deviation for the profile samples at M2 at these low concentrations of $11.7 \%$. Accuracy was determined using Certified International Standard Material NASS-5 (National Research Council of Canada) that was processed in the same way as the samples (Table 2).

\section{Results and Discussion}

\subsection{Hydrography}

[22] Sites M1 and M3 are bounded to the west and north by the SAF, thus they receive little influence from

Table 2. Trace Metal Values for Certified Reference Materials $(n=3)^{\mathrm{a}}$

\begin{tabular}{lcccc}
\hline & NASS-6 Certified Value & This Study & CASS-5 Certified Value & This Study \\
\hline $\mathrm{Ni}$ & $0.301 \pm 0.025$ & $0.286 \pm 0.008$ & $0.330 \pm 0.023$ & $0.302 \pm 0.011$ \\
$\mathrm{Zn}$ & $0.257 \pm 0.020$ & $0.200 \pm 0.020$ & $0.719 \pm 0.068$ & $0.664 \pm 0.013$ \\
$\mathrm{Co}$ & 0.015 & $0.015 \pm 0.001$ & 0.095 & $0.091 \pm 0.002$ \\
$\mathrm{Cd}$ & $0.0311 \pm 0.0019$ & $0.0350 \pm 0.0033$ & $0.0215 \pm 0.0018$ & $0.0232 \pm 0.0029$ \\
$\mathrm{~Pb}$ & $0.006 \pm 0.002$ & $0.006 \pm 0.001$ & $0.011 \pm 0.002$ & $0.010 \pm 0.001$ \\
& NASS-5 certified value & This study & & \\
$\mathrm{Mn}$ & $0.919 \pm 0.057$ & $0.917 \pm 0.055$ & & \\
\hline
\end{tabular}

${ }^{\mathrm{a}} 95 \%$ of confidence limits are presented. All concentrations are in $\mu \mathrm{g} \mathrm{L}{ }^{-1}$. Due to low recovery $(<90 \%)$, Cd data presented in this study and in this table have been recovery corrected. 


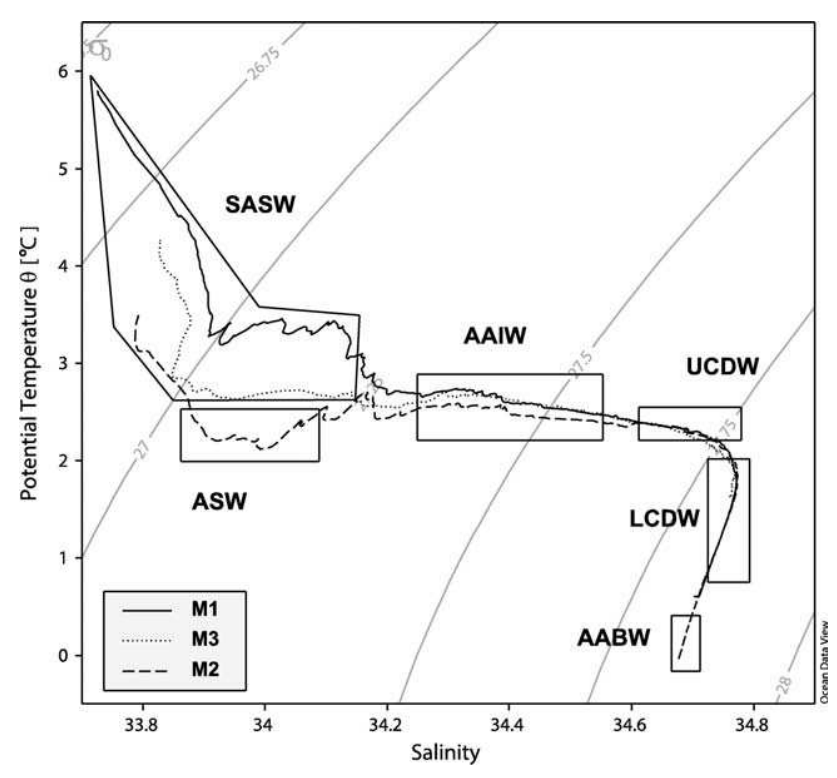

Figure 2. Potential temperature $\left({ }^{\circ} \mathrm{C}\right)$ versus salinity for sites M1, M3, and M2. Water mass abbreviations in alphabetical order: AABW: Antarctic Bottom Water; AAIW: Antarctic Intermediate Water; AASW: Antarctic Surface Water; LCDW : Lower Circumpolar Deep Water; SASW : Sub-Antarctic Surface Water; and UCDW : Upper Circumpolar Deep Water. Figure made with Ocean Data View (R. Schlitzer, 2011, Ocean data view, version 4.3.10, http:// odv.awi.de).

subtropical waters (Figure 1). Nevertheless, there is evidence of eddies penetrating from the SAF [Pollard et al., 2007a; Read et al., 2007] causing the Chl- $a$ patchiness observed in the satellite imagery [Venables et al., 2007]. Surface waters $(\mathrm{S}<34.2)$ (Figures 2 and 3 ) had similar physical properties to those found in a nearby station by Read et al. [2007] and were related to Sub-Antarctic Surface Water (SASW) (Figure 2). Upper $300 \mathrm{~m}$ of the water column at M3 was also identified as SASW by Charette et al. [2007] based on ${ }^{226} \mathrm{Ra}$ activities. Attribution of intermediate and deep waters at M3 is rather difficult and Charette et al. [2007] suggested a mixture of Antarctic Intermediate Water (AAIW) and underlying Circumpolar Deep Water (CDW). Macronutrients cyclings, ratios, and concentrations at M2 were typical of Southern Ocean HNLC regions [Pollard et al., 2007b; Sanders et al., 2007].

[23] M2 was, therefore, chosen as a control representative of typical HNLC conditions, although Argo floats show that water from the islands or the plateau may occasionally reach this site [Pollard et al., 2007a]. Surface waters (Figures 2 and 3) possibly show the mixture of SASW and Antarctic Surface Water (AASW) as the subsurface minimum in the potential temperature $\left(\theta<2.1^{\circ} \mathrm{C}\right)$ is typical for AASW of the Antarctic Zone (AAZ), which suggests that M2 is likely south of the PF. This is consistent with a detailed description of water masses around the Crozet Plateau and Basin reported by Park et al. [1993] and more recent findings by Read et al. [2007]. Intermediate waters extending from $\sim 300$ to $\sim 800 \mathrm{~m}$ were assumed to belong to the relatively fresh AAIW in agreement with the water mass classification adopted in a nearby station [Charette et al., 2007]. The underlying water mass extending up to 3000-3500 m showed a gradual decrease in temperature and an increase in salinity with depth probably corresponding to Circumpolar Deep Water (CDW). This water mass often distinguished between Upper (UCDW) and Lower (LCDW) branches showed a salinity maximum $(S>34.77)$ at $2000 \mathrm{~m}$ likely due to the influence from more saline North Atlantic Deep Water (NADW). Below $\sim 3500 \mathrm{~m}$, colder and fresher $(\theta<0.3$ and $S<34.71)$ water was found and attributed to Antarctic Bottom Water (AABW) as it is documented that AABW passes near Crozet on its way to the Indian Ocean [Mantyla and Reid, 1983; Park et al., 1993].

\subsection{Trace Metal Distributions}

[24] Depth profiles for each of the trace metals (Ni, Zn, $\mathrm{Co}, \mathrm{Cd}$, and $\mathrm{Pb}$ ) are plotted along with potential temperature for the three studied sites (M1, M2, and M3) in Figure 3. A1 and $\mathrm{Mn}$ data are only available for M2 (Figure 3). Table 3 provides a general comparison of dissolved trace metal concentrations obtained in this study and previous work in the Southern Ocean. Macronutrients nitrate, phosphate, and $\mathrm{Si}$ are plotted in Figure 4. Nutrient-metal correlations are calculated in order to assess surface (upper $250 \mathrm{~m}$, Table 4) biological uptake of bioactive trace metals in the bloom area and their recycling in deep waters. Errors included in the correlations are quoted to one standard deviation.

\subsubsection{Nickel}

[25] Vertical profiles for dissolved Ni showed surface depletion and regeneration with depth occurring along with macronutrients at all stations (Figures 3 and 4). $\mathrm{Ni}$ increased by $\sim 1 \mathrm{nM}$ with increasing depth and showed little variation below $1000 \mathrm{~m}$. Dissolved Ni concentrations ranged from 4.6 to $6.3 \mathrm{nM}$ (Figure 3 ) and are consistent with the recently reported concentrations of 3-6 nmol kg-1 for wintertime sub-Antarctic waters south of Australia [Ellwood, 2008], 2.2-6.6 nM for the upper $300 \mathrm{~m}$ in the Australian PFZ [Lai et al., 2008] and earlier work in the Southern Ocean (Table 3).

[26] Strong correlation of $\mathrm{Ni}$ with nitrate (slope $=0.09$, intercept $\left.=3.03, r^{2}=0.81 ; n=50 ; p<0.001\right)$ and Ni with phosphate (slope $=1.23$, intercept $=3.11, r^{2}=0.77 ; n=50$; $p<0.001)$ and moderate correlations of $\mathrm{Ni}$ with $\mathrm{Si}$ (slope $=0.01$, intercept $=5.16, r^{2}=0.58 ; n=50 ; p<0.001$ ) were found using the entire data set. Similar strong correlations with phosphate were reported for Australian subAntarctic waters [Butler et al., 2013; Ellwood, 2008], whereas Lai et al. [2008] found much weaker relationships $\left(r^{2}=0.50\right)$ in that region.

[27] Dissolved Ni was highly correlated with all macronutrients in the upper $250 \mathrm{~m}$ (Table 4) north of the islands (M1) where higher biomass and primary production is found [Seeyave et al., 2007; Venables et al., 2007] confirming surface $\mathrm{Ni}$ and macronutrient uptake within the bloom area (Figures 3 and 4, Table 4). The small depletion of $\mathrm{Ni}$ (typically $0.5-1 \mathrm{nM}$ ) in the bloom area north of Crozet is comparable to findings of Ellwood [2008] and Butler et al. [2013], who suggested a low biological requirement of $\mathrm{Ni}$ compared to other macronutrients in waters of the subAntarctic and Polar Frontal Zones south of Australia. This is corroborated by the positive intercept in excess of $3 \mathrm{nM}$ calculated at $\mathrm{M} 1$ between $\mathrm{Ni}$ and all macronutrients 

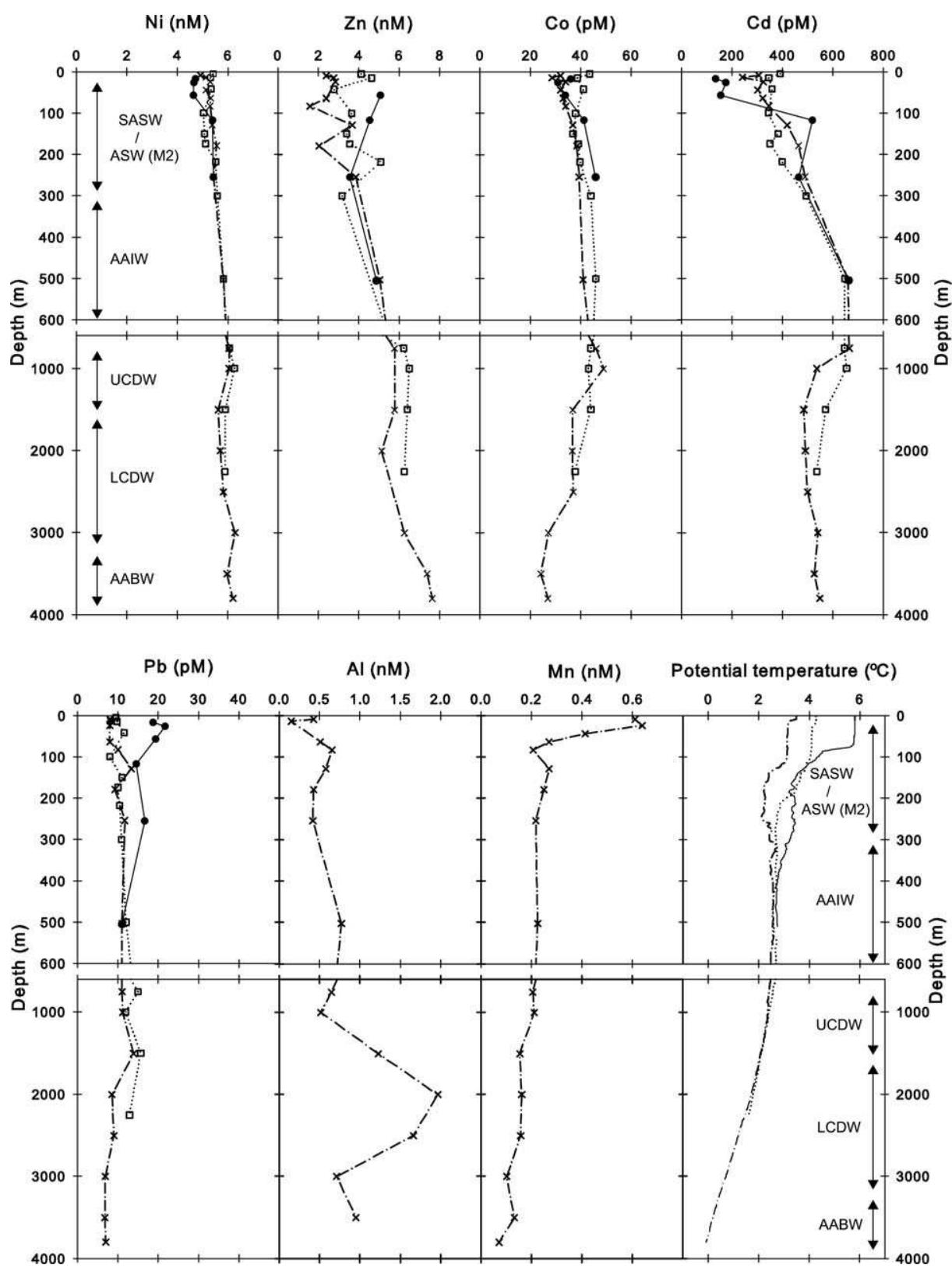

Figure 3. Vertical profiles of dissolved $\mathrm{Ni}, \mathrm{Zn}, \mathrm{Co}, \mathrm{Cd}, \mathrm{Pb}, \mathrm{Al}$, and $\mathrm{Mn}$ along with potential temperature for sites M1 (filled circle, solid line), M3 (empty square, dotted line), and M2 (cross, dash-dot line). Note the different scale on the $y$ axis. Water mass abbreviations in alphabetical order: AABW : Antarctic Bottom Water; AAIW: Antarctic Intermediate Water; AASW: Antarctic Surface Water; LCDW: Lower Circumpolar Deep Water; SASW : Sub-Antarctic Surface Water; and UCDW : Upper Circumpolar Deep Water.

(Table 4) which indicates that an excess of Ni will persist even in the case of macronutrient depletion.

[28] Depletion of trace metals including dissolved $\mathrm{Ni}$ have been reported elsewhere, for example, during a spring diatom bloom in the PFZ [Löscher, 1999] and in an artificial Fe experiment in the HNLC sub-Arctic Pacific [Kinugasa et al., 2005], whereas no apparent Ni uptake was observed during the Southern Ocean Iron RElease Experiment (SOIREE) in the Southern Ocean [Frew et al., 2001].

[29] Depletion of Ni and Si at M1 were largest relative to nonbloom sites (Figures 3 and 4), and high correlations between the two elements in the upper $250 \mathrm{~m}$ were found only here (Table 4) suggesting that Ni uptake was linked to the presence of diatoms. At the time of sampling, the bloom was already in decline and the phytoplankton community was dominated by Phaeocystis antarctica but diatoms still accounted for $38 \%$ of the biomass at M1 [Poulton et al., 2007]. Furthermore, diatoms species Eucampia antarctica were dominant in sediment traps north of the plateau and accounted for $72-100 \%$ of the particle export [Salter et al., 2007]. The presence of diatoms was also confirmed during short-term incubation experiments on board where 
Table 3. Comparison of Reported Ranges for Dissolved $\mathrm{Ni}, \mathrm{Zn}, \mathrm{Co}, \mathrm{Cd}, \mathrm{Pb}, \mathrm{Al}$, and $\mathrm{Mn}$ in the Southern Ocean

\begin{tabular}{|c|c|c|c|c|c|c|c|c|c|c|}
\hline Study & Location & Season $^{\mathrm{a}}$ & Depth $^{\mathrm{b}}$ & $\mathrm{Ni}(\mathrm{nM})$ & $\mathrm{Zn}(\mathrm{nM})$ & $\mathrm{Co}(\mathrm{pM})$ & $\mathrm{Cd}(\mathrm{pM})$ & $\mathrm{Pb}(\mathrm{pM})$ & $\mathrm{Al}(\mathrm{nM})$ & $\mathrm{Mn}(\mathrm{nM})$ \\
\hline This study & Indian sector, Crozet Islands & Spring & 3800 & $4.64-6.31$ & $1.59-7.75$ & $24-49^{c}$ & $135-673$ & $6-22$ & $0.13-2.15$ & $0.07-0.64$ \\
\hline Butler et al. [2013] & Australian sector & Late summer & $\sim 1000$ & $2.51-7.31$ & $<0.22-1.79$ & $5-43$ & $\sim 4-900$ & & & \\
\hline Boye et al. [2012] & Southeast Atlantic sector & Summer & $\sim 4000$ & & & & 4-895 & $7-55$ & & $\sim 0.2-1.3$ \\
\hline Bown et al. [2012] & Indian sector, Kerguelen Plateau & Summer & 2500 & & & $19-375^{\mathrm{c}}$ & & & & \\
\hline Middag et al. [2012] & Drake Passage & Autumn & 4250 & & & & & & $0.09-14.43$ & $0.08-2.64$ \\
\hline Abouchami et al. $[2011]^{\mathrm{d}}$ & Atlantic sector, Zero meridian & late Summer & Surface & & & & $36-620$ & & & \\
\hline Bown et al. [2011] & Atlantic sector, Zero meridian & Summer & 4000 & & & $5-74^{\mathrm{c}}$ & & & & \\
\hline Croot et al. [2011] & Atlantic sector & Autumn & $>5000$ & & $0.21-7.00$ & & & & & \\
\hline Middag et al. [2011a] & Atlantic sector, Zero meridian & Summer & 5320 & & & & & & $0.10-6.54$ & \\
\hline Middag et al. [2011b] & Atlantic sector, Zero meridian & Summer & 5320 & & & & & & & $0.05-3.20$ \\
\hline \multirow[t]{2}{*}{ Saito et al. [2010] } & Ross Sea & Spring & $>1400$ & & & $40-85^{\mathrm{c}}$ & & & & \\
\hline & & Summer & $>1400$ & & & $20-60^{\mathrm{c}}$ & & & & \\
\hline Ellwood $[2008]^{\mathrm{d}}$ & Australian sector, sub-Antarctic zone & Winter & 1000 & $3.00-7.00$ & $0-3.00$ & $10-50$ & $20-650$ & $12-33$ & & \\
\hline Lai et al. [2008] & Australian sector, $140^{\circ}$ meridian & Summer & 300 & $2.15-7.91$ & & & & $6-170$ & & \\
\hline Coale et al. $[2005]^{\mathrm{d}}$ & Ross Sea and ACC $\left(170^{\circ} \mathrm{W}\right)$ & Spring-summer & 2000 & & $0.18-6.54$ & & & & & \\
\hline Corami et al. $[2005]^{\mathrm{d}}$ & Ross Sea & Summer & 1580 & & $2.2-11.9$ & & $340-900$ & $3-127$ & & $0.33-4.10$ \\
\hline Ellwood et al. [2005] & Atlantic sector, across the PF & Autumn & 1000 & & & $15-45^{\mathrm{c}}$ & & & & \\
\hline \multirow{2}{*}{ Abollino et al. [2004] } & Ross Sea & Spring & 250 & $5.2-9.4$ & & & $420-800$ & & & $0.2-1.9$ \\
\hline & Gerlache Inlet & Spring & 380 & $3.5-11.5$ & & & $100-580$ & & & $0.5-2.5$ \\
\hline Sañudo-Wilhelmy et al. [2002] & Weddell Sea & Summer & Surface & $5.10-6.52$ & $1.44-5.99$ & $18-172$ & $170-670$ & $4-40$ & $1.21-5.78$ & \\
\hline Frew et al. [2001] & Australian sector, $61^{\circ} \mathrm{S}-140^{\circ} \mathrm{E}$ & Summer & 40 & $5.7-6.6$ & $1.9-2.5$ & & $120-280$ & & & \\
\hline Bucciarelli et al. [2001] & Indian sector, Kerguelen Islands & Autumn & 280 & & & & & & & $0.68-8.54$ \\
\hline Grotti et al. [2001] & Gerlache Inlet & Spring & 380 & & & & & & & $0.10-6.60$ \\
\hline Fitzwater et al. $[2000]^{\mathrm{d}}$ & Ross Sea & Summer & 375 & $4.78-6.88$ & $0.24-7.11$ & $5-41$ & $40-800$ & & & \\
\hline Sedwick et al. [2000] & Ross Sea & Spring-summer & 300 & & & & & & & $0.03-0.83$ \\
\hline Löscher [1999] & Atlantic sector, $6^{\circ} \mathrm{W}$ meridian & Spring & 4225 & $3.70-7.55$ & $0.8-10$ & & & & & \\
\hline Löscher et al. [1998] & Atlantic sector, $6^{\circ} \mathrm{W}$ meridian & Spring & 4839 & & & $155-1309$ & & & & \\
\hline Sedwick et al. [1997] & Australian sector, sub-Antarctic zone & Summer & 350 & & & & & & & $0.09-2.25$ \\
\hline van Beusekom et al. [1997] & Indian sector, Enderby and Crozet Basins & Autumn & $>5000$ & & & & & & $0.10-4.09$ & \\
\hline Nolting and de Baar [1994] & Scotia-Weddell Seas & Spring & 300 & $3.07-10.39$ & $1.38-13.91$ & & $170-950$ & & & \\
\hline Moran et al. $[1992]^{\mathrm{e}}$ & Weddell Sea & Summer & 4100 & & & & & & $1.0-4.9$ & \\
\hline van Bennekom et al. $[1991]^{\mathrm{e}}$ & Scotia-Weddell Seas & Spring-summer & $\sim 4000$ & & & & & & $1.0-3.1$ & \\
\hline Westerlund and Öhman [1991a] & Weddell Sea & Summer & 3250 & & & & & & & $0.11-2.07$ \\
\hline Westerlund and Öhman [1991b] & Weddell Sea & Summer & 4000 & $5.08-8.23$ & $1.88-8.00$ & $12-58$ & 480-970 & $\sim 10$ & & \\
\hline Nolting et al. [1991] & Scotia-Weddell Seas & Spring-summer & 3931 & & & & $290-990$ & & & \\
\hline Martin et al. $[1990]^{\mathrm{d}}$ & Drake Passage and Gerlache Strait & Summer & 1420 & & $0.24-6.34$ & $21-82$ & $260-810$ & & & $0.08-5.05$ \\
\hline
\end{tabular}

${ }^{\mathrm{a}}$ Seasons are given for the Southern Hemisphere.
${ }^{\mathrm{b}}$ Maximum sampled depth in meters.

${ }^{\mathrm{b}}$ Maximum sampled depth in meters.

${ }^{\mathrm{C}} \mathrm{UV}$-digested data for dissolved $\mathrm{Co}$.

${ }^{\mathrm{d}}$ Data per kilogram of seawater.

${ }^{\mathrm{e}}$ Unfiltered samples. 


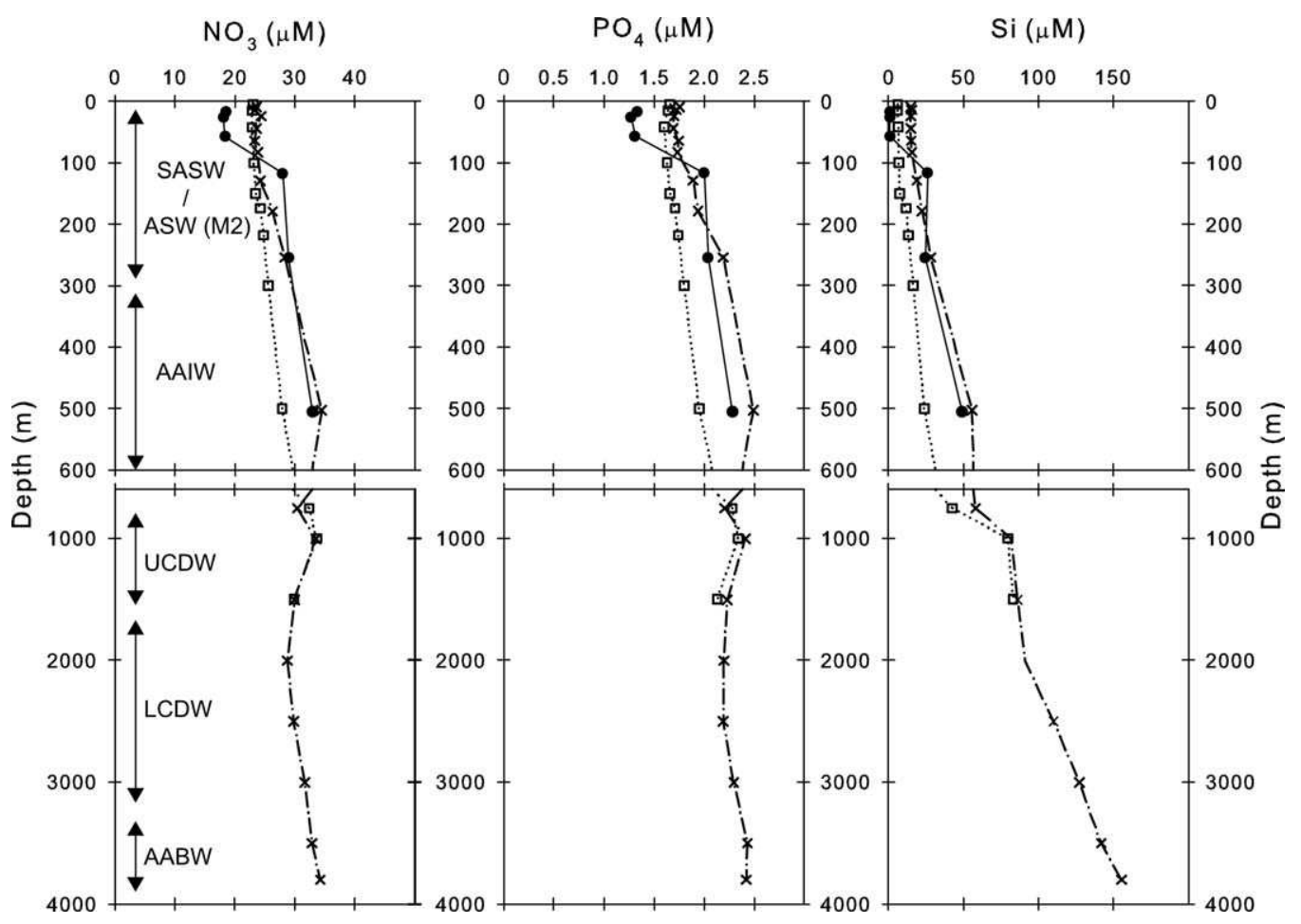

Figure 4. Vertical profiles of nitrate, phosphate, and Si for sites M1 (filled circle, solid line), M3 (empty square, dotted line), and M2 (cross, dash-dot line). Note the different scale on the $y$ axis. Water mass abbreviations in alphabetical order: AABW: Antarctic Bottom Water; AAIW: Antarctic Intermediate Water; AASW : Antarctic Surface Water; LCDW : Lower Circumpolar deep Water; SASW : SubAntarctic Surface Water; and UCDW: Upper Circumpolar Deep Water.

medium-sized diatoms showed a strong response upon $\mathrm{Fe}$ addition suggesting that these organisms were important at the beginning of the bloom [Moore et al., 2007]. Finally, synchrotron X-ray fluorescence analysis of phytoplankton cells has revealed that diatoms have 2 to 5 -fold higher $\mathrm{Ni}$ quotas than other phytoplankton groups [Twining et al., 2004, 2011, 2012] and that $\mathrm{Ni}$ is equally accumulated in the intracellular material and the frustules [Twining et al., 2012], supporting the strong depletion observed at M1.

Table 4. Significant $(p<0.01)$ Correlations Between Dissolved Trace Metals and Inorganic Nutrients in the Upper $250 \mathrm{~m}$ of Crozet Waters $^{\mathrm{a}}$

\begin{tabular}{lcccccccc}
\hline & Site & $n$ & Slope & \pm & $P$ Value & Intercept & $+/-$ & $R^{2}$ \\
\hline $\mathrm{Ni}: \mathrm{P}$ & $\mathrm{M} 1$ & 5 & 1.03 & 0.03 & $<0.001$ & 3.33 & 0.05 & 0.99 \\
$\mathrm{Ni}: \mathrm{N}$ & $\mathrm{M} 1$ & 5 & 0.07 & 0.00 & $<0.001$ & 3.33 & 0.06 & 0.99 \\
$\mathrm{Ni}: \mathrm{Si}$ & $\mathrm{M} 1$ & 5 & 0.03 & 0.00 & $<0.001$ & 4.64 & 0.03 & 0.99 \\
$\mathrm{Co}: \mathrm{P}$ & $\mathrm{M} 2$ & 15 & 16 & 4 & $<0.01$ & 4 & 7 & 0.54 \\
$\mathrm{Co}: \mathrm{N}$ & $\mathrm{M} 2$ & 15 & 2 & 0 & $<0.01$ & -6 & 10 & 0.57 \\
$\mathrm{Co}: \mathrm{Si}$ & $\mathrm{M} 2$ & 15 & 1 & 0 & $<0.01$ & 24 & 2 & 0.56 \\
$\mathrm{Cd}: \mathrm{P}$ & $\mathrm{M} 1$ & 5 & 465 & 52 & $<0.01$ & -449 & 84 & 0.96 \\
$\mathrm{Cd}: \mathrm{N}$ & $\mathrm{M} 1$ & 5 & 33 & 4 & $<0.01$ & -446 & 86 & 0.96 \\
$\mathrm{Cd}: \mathrm{Si}$ & $\mathrm{M} 1$ & 5 & 14 & 1 & $<0.001$ & 144 & 12 & 0.99 \\
$\mathrm{Cd}: \mathrm{P}$ & $\mathrm{M} 2$ & 15 & 441 & 66 & $<0.001$ & -447 & 119 & 0.77 \\
$\mathrm{Cd}: \mathrm{N}$ & $\mathrm{M} 2$ & 15 & 42 & 7 & $<0.001$ & -681 & 168 & 0.74 \\
$\mathrm{Cd}: \mathrm{Si}$ & $\mathrm{M} 2$ & 15 & 15 & 2 & $<0.001$ & 85 & 36 & 0.80 \\
\hline
\end{tabular}

${ }^{a}$ One standard deviation of slope and intercept are indicated in columns with \pm . Slopes are in $\mathrm{nmol} / \mu \mathrm{mol}$ for $\mathrm{Ni}$ and $\mathrm{pmol} / \mu \mathrm{mol}$ for $\mathrm{Co}$ and $\mathrm{Cd}$. Intercepts are in $\mathrm{nmol} / \mathrm{L}$ for $\mathrm{Ni}$ and $\mathrm{pmol} / \mathrm{L}$ for $\mathrm{Co}$ and $\mathrm{Cd}$.
Incorporation of $\mathrm{Ni}$ intro frustules is not yet understood but it is known that $\mathrm{Ni}$ is required by diatoms for the assimilation of urea [Oliveira and Antia, 1984; Price and Morel, 1991] and replacement of $\mathrm{Fe}$ by $\mathrm{Ni}$ in enzyme superoxide dismutase (SOD) appears to be a common adaptation to low Fe concentrations [Cuvelier et al., 2010]. Under these conditions, assimilation of $\mathrm{Ni}$ using divalent metal transporters [Agranoff et al., 2005] in a similar way to $\mathrm{Fe}$ [Kustka et al., 2007] could also be considered.

\subsubsection{Zinc}

[30] Vertical profiles showed a nutrient-like behavior of $\mathrm{Zn}$ with regeneration occurring together with inorganic nutrients and particularly with $\mathrm{Si}$ in surface and intermediate waters (Figures 3, 4 and 5) of all stations. From 1000 to $2000 \mathrm{~m} \mathrm{Zn}$ was rather invariant (M2 and M3) and increased again along with $\mathrm{Si}$ reaching maximum concentrations in deep waters at M2.

[31] Dissolved $\mathrm{Zn}$ generally ranged between 2 and $6 \mathrm{nM}$ (Figure 3) although, maximum concentrations as high as $7.75 \mathrm{nM}$ were found at the greatest sampled depth $(3750 \mathrm{~m}$, M2) coinciding with a colder and fresher nutrient-rich water mass identified here as AABW (Figure 2). These deep water concentrations were $\sim 1.5 \mathrm{nM}$ higher than those reported for the Zero meridian across the PFZ [Croot et al., 2011] but similar to those found in the Madagascar Basin that were also attributed to AABW [Morley et al., 1993]. The range of our dissolved $\mathrm{Zn}$ concentrations is slightly higher in magnitude than the $0.5-6 \mathrm{nM}$ range reported for the PFZ in the Atlantic sector (stations S103 \& S104 of Croot et al. [2011]) but lower than the 0.4-12.1 nM 

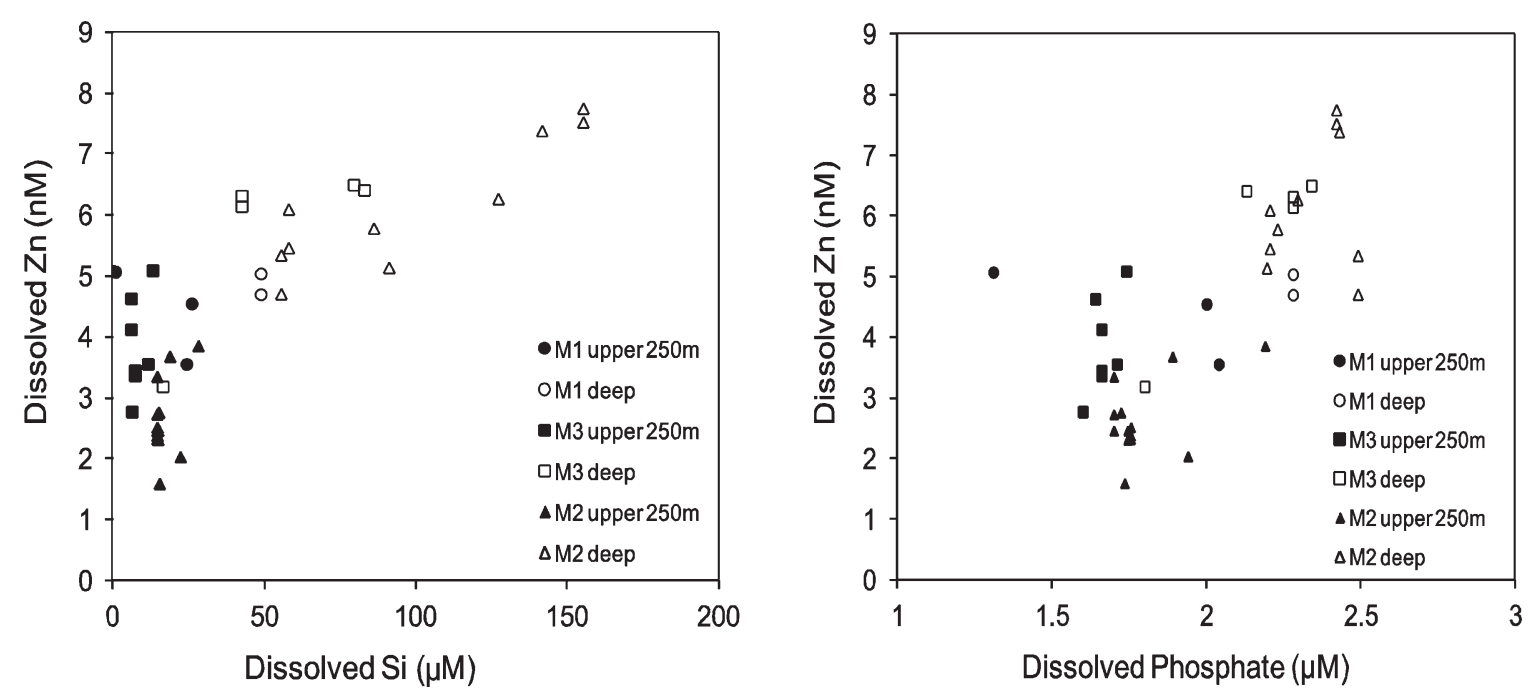

Figure 5. (left) Dissolved $\mathrm{Zn}(\mathrm{nM})$ versus $\mathrm{Si}(\mu \mathrm{M})$ and (right) dissolved phosphate $(\mu \mathrm{M})$ for sites $\mathrm{M} 1$ (circle), M3 (square), and M2 (triangle). Filled and empty symbols indicate surface and deep water data, respectively.

for the southwestern Indian Ocean [Morley et al., 1993]. Ellwood [2008] reported lower wintertime concentrations of $0.5-3.5 \mathrm{nmol} \mathrm{kg}^{-1}$ for the upper $500 \mathrm{~m}$ in the Australian sub-Antarctic zone and recent work by Gosnell et al. [2012] found $\mathrm{Zn}$ concentrations from $0.02 \mathrm{nM}$ in the surface up to $>3.5 \mathrm{nM}$ at about $1300 \mathrm{~m}$ in the southern Indian Ocean. Their stations, however, were located further north and had less influence from nutrient and metal-rich Antarctic waters, therefore, higher $\mathrm{Zn}$ values around Crozet were expected. Other studies including dissolved $\mathrm{Zn}$ in the Southern Ocean generally obtained higher or similar values to this study (Table 3).

[32] At the time of sampling, surface Si reached limiting values of $<1 \mu \mathrm{M}$ at M1 [Poulton et al., 2007] and dissolved Fe concentrations were moderately limiting, with an average of $0.35 \mathrm{nM}$ in the upper $250 \mathrm{~m}$ [Planquette et al., 2007]. As mentioned above (section 3.2.1), diatoms were dominating the earlier stages of the bloom [Moore et al., 2007; Poulton et al., 2007; Salter et al., 2007], which probably explains Si and Fe drawdown. Diatom growth li- mitation by silicic acid in PFZ waters of the Crozet Basin has also been reported by Sedwick et al. [2002] and diatom cultures have shown that $\mathrm{Zn}$ is required for Si uptake [De La Rocha et al., 2000; Rueter and Morel, 1981]. Unfortunately, no enhanced biological uptake of Zn nor strong correlations with $\mathrm{Si}$ were appreciable in surface waters at M1 due to analytical scatter and limited data (some surface samples appeared to be contaminated during sampling or handling and did not prove to be oceanographically consistent. Details can be found in supporting information). The moderate correlation of $\mathrm{Zn}$ with Si (Figure 5) when considering the whole data set (slope $=0.032$, intercept $=3.02$, $\left.r^{2}=0.66 ; \mathrm{n}=40 ; p<0.001\right)$, however, suggests that likely diatoms significantly influenced the biogeochemical cycling of $\mathrm{Zn}$ around Crozet.

[33] Croot et al. [2011] provide a comparison of $\mathrm{Zn}: \mathrm{Si}$ ratios with particular emphasis on the Southern Ocean. Our low overall ratio of $0.032 \mathrm{nmol} \mathrm{Zn}: \mu \mathrm{mol} \mathrm{Si}$ found in Crozet waters was similar to the ratio of $0.033 \mathrm{nmol} \mathrm{Zn}: \mu \mathrm{mol} \mathrm{Si}$ reported for productive waters of the ACC [Löscher, 1999]
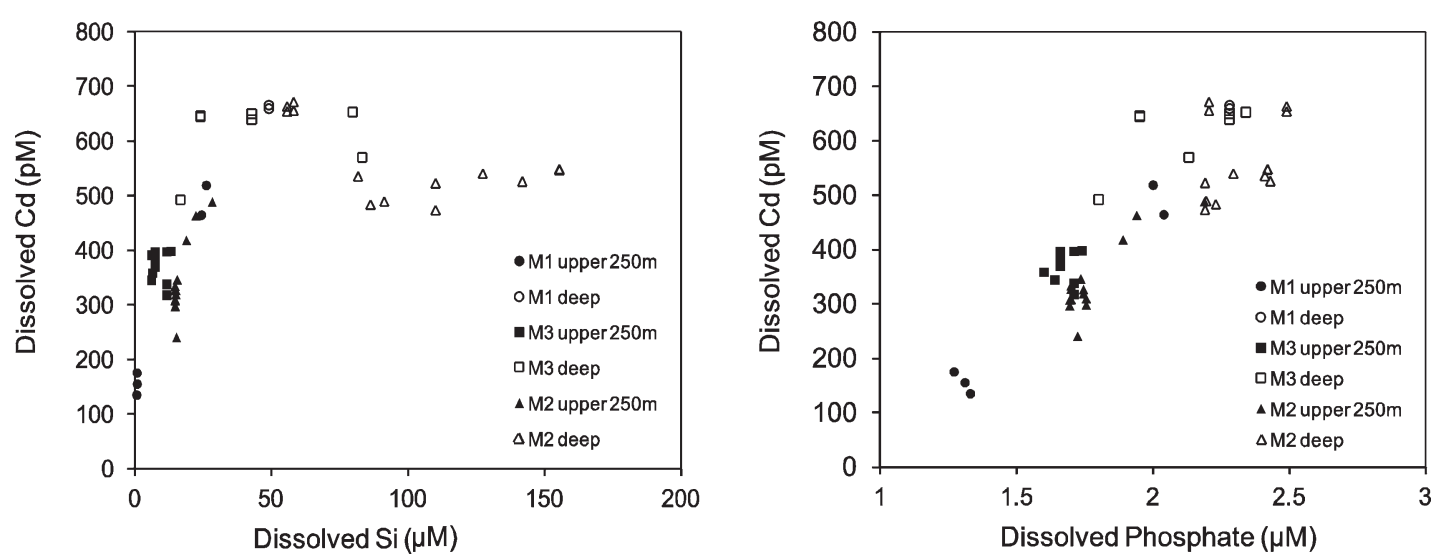

Figure 6. Dissolved $\mathrm{Cd}(\mathrm{pM})$ versus (left) $\mathrm{Si}(\mu \mathrm{M})$ and (right) dissolved phosphate $(\mu \mathrm{M})$ for sites M1 (circle), M3 (square), and M2 (triangle). Filled and empty symbols indicate surface and deep water data, respectively. 
but lower than for the southern Indian Ocean [Gosnell et al., 2012], the Zero meridian [Croot et al., 2011] and the Australian sub-Antarctic zone [Ellwood, 2008]. Waters north of Crozet receive a natural supply of dissolved Fe (Fe concentrations of $0.35 \mathrm{nM}$ in the upper $250 \mathrm{~m}$ of station M1) that supports high primary production rates during spring and summer [Planquette et al., 2007] which may explain the lower utilization of $\mathrm{Zn}$ compared to other Fe deprived HNLC waters in the Southern Ocean.

[34] Furthermore, $\mathrm{Zn}$ concentrations at M3 were $\sim 0.7$ $\mathrm{nM}$ higher than at M1 and M2 throughout most of the water column. Although this increase is not clearly related to an island source, sediments from Crozet plateau and islands have been shown to supply dissolved and particulate $\mathrm{Fe}$ [Planquette et al., 2009; Planquette et al., 2007], and to a lesser extent, particulate aluminium [Planquette et al., 2009]. Similarly, higher $\mathrm{Zn}$ values were reported and associated with advective inputs from coastal and shelf processes in the sub-Arctic northeast Pacific [Lohan et al., 2002]. Horizontal advection is important in the vicinity of Île de la Possession and Île de l'Est, as well as at M3 [Charette et al., 2007] and constitutes the main input of $\mathrm{Fe}$ [Planquette et al., 2007], indicating that Crozet could act as source of Zn. The fact that Fe [see Planquette et al., 2007] and $\mathrm{Zn}$ have similar variations in the upper $250 \mathrm{~m}$ of M3 strengthens this hypothesis. Upwelling of deep waters is highly improbable at M3 due to its proximity to a steep bathymetric change [Pollard et al., 2007a; R. Pollard, personal communication, 2011].

\subsubsection{Cobalt}

[35] Vertical profiles of Co reflected different behaviors in the three distinct biogeochemical regions around Crozet. Overall, dissolved Co concentrations ranged from 24 to 49 pM (Figure 3). Since the samples were UV irradiated, they are deemed to be true total dissolved values. UV digested concentrations for dissolved Co were reported elsewhere: Saito et al. [2010] reported concentrations in the Ross Sea between 20 and $85 \mathrm{pM}$ during spring-summer and Bown et al. [2011] reported a range of 5-74 pM during the summertime in the southeast Atlantic sector. In the subAntarctic zone of the Australian sector, non-UV irradiated concentrations of dissolved Co ranged from 10 to $50 \mathrm{pmol}$ $\mathrm{kg}^{-1}$ in the wintertime [Ellwood, 2008] and were comparable to the range of 5-43 pM found during late summer by Butler et al. [2013]. Our data are in good agreement with these values and in line with other published data for the Southern Ocean (Table 3). Finally, Bown et al. [2012] reported concentrations as high as $375 \mathrm{pM}$ around Kerguelen and argued an island source of Co to adjacent waters. Such an island source is not obvious at our offshore sampling sites around Crozet.

[36] In this study, surface Co concentrations were more depleted at M2 ( 34 pM) than at M1 (38 pM) and M3 (40 $\mathrm{pM})$. However, the magnitude of the depletion compared to the average mesopelagic concentration was greater at M1 than at M2, probably indicating biological uptake. Lower surface Co concentrations related to biological uptake have been previously reported in the sub-Antarctic zone [Bown et al., 2011; Ellwood, 2008] and the Ross Sea [Saito et al., 2010]. Such an uptake is visible at M1, where Co is moderately correlated with all macronutrients in surface (correlation with phosphate: $r^{2}=0.87, n=5$; nitrate: $r^{2}=0.87, n=5$; $\mathrm{Si}$ : $\left.r^{2}=0.80, n=5 ; p<0.05\right)$. At M2, lower correlations were found (Table 4), which is consistent with this station being a HNLC site. At M3, dissolved Co concentrations were rather invariant throughout the water column and no correlation was noted between dissolved Co and macronutrients, probably due to the strong vertical mixing observed by Charette et al. [2007]. Alternatively, dissolved Co might have been strongly scavenged in the euphotic layer by a higher vertical particles export highlighted by Morris et al. [2007], essentially at station M1. Finally, the absence or the lack of organic ligands may also have limited the stabilization of Co in the dissolved fraction, thus decreasing its residence time [Bown et al., 2012]. At M2, a strong recycling component in the upper $1000 \mathrm{~m}$ can be observed then followed by a decrease with increasing depth (Figure 3 ). Scavenging processes likely explain most of the distribution of dissolved Co concentrations at intermediate and deep waters, particularly at M2. At this station, intrusions of CDW at about 1000 $1500 \mathrm{~m}$, then AABW at 3000-3500 m, may explain the observed distribution. CDW and AABW should have been more exposed than AAIW to the removal by sinking particles during their longer circulation pathways. Removal of dissolved Co linked to adsorption onto particles has been also suggested by Bown et al. [2011] to explain the lower Co concentrations found in deep waters of the Antarctic Circumpolar Current. Overall, Co data presented in this study generally agree very well with recent data reported for the Atlantic sector [Bown et al., 2011], where scavenging and mixing of water masses have been shown to exert a major control on the vertical distribution of Co within the PFZ.

\subsubsection{Cadmium}

[37] Vertical profiles of Cd showed the strongest surface drawdown and shallowest regeneration among the targeted metals of this study (Figure 3). Below 1000 m, Cd concentrations decreased by $\sim 100 \mathrm{pM}$ and remained constant before slightly increasing again at greatest depths.

[38] Dissolved Cd concentrations ranged from 135 to 673 pM (Figure 3) which is in line with the recently reported range of 36-620 pM for the Australian sub-Antarctic zone [Ellwood, 2008] and other areas of the Southern Ocean (Table 3).

[39] As with $\mathrm{Ni}$, lowest surface concentrations for $\mathrm{Cd}$ were found at M1. At this station, the decrease in the top $250 \mathrm{~m}$ of $\mathrm{Cd}$ and Co corresponds to an increase in $\mathrm{Zn}$ concentration. This might be explained by the fact that $\mathrm{Zn}, \mathrm{Co}$, and $\mathrm{Cd}$ can all act as a substitute into the active site of the enzyme carbonic anhydrase, depending on the species [Sunda, 2012]. Cd was also well correlated with macronutrients phosphate and Si (Figure 6) and, with nitrate in the upper $250 \mathrm{~m}$ of Station M1 (Table 4). In the upper $250 \mathrm{~m}$ of Station M3, Cd/phosphate ratio was on average of 0.441 nmol Cd: $\mu$ mol phosphate. These strong correlations indicate that the depletion of $\mathrm{Cd}$ of $>100 \mathrm{pM}$ and subsequent recycling are driven by biological processes [Lane and Morel, 2000]. Phytoplankton uptake of $\mathrm{Cd}$ has been reported in sub-Antarctic waters south of Australia [Ellwood, 2008], in artificial Fe experiments [Frew et al., 2001; Kinugasa et al., 2005] and is evident in bottle incubations [Nakatsuka et al., 2009].

[40] The slope and nonzero intercept found for $\mathrm{Cd}$ against phosphate (Table 4) is typical of the Southern Ocean [de Baar et al., 1994] and similar to the one reported 
by Ellwood [2008] in the sub-Antarctic region. Table 4 and Figure 6 suggest that $\mathrm{Cd}$ uptake is enhanced to that of phosphate in HNLC waters with limiting Fe [Cullen et al., 2003]. Stations analyzed here were sampled once the main bloom collapsed [Venables et al., 2007] and some sites such as M3 already showed Fe limiting conditions [Planquette et al., 2007]. Explanation for higher Cd concentrations at M3 compared to M2 at depths of $1000-2500 \mathrm{~m}$ is not straightforward and possibly implies a combination of a sedimentary source (based on some small increases in dissolved Cd observed close to the islands) and the general sinking trend of Antarctic waters as they move northward.

[41] The transition from AAIW to CDW may also explain the lower $\mathrm{Cd}$ found below $1000 \mathrm{~m}$ as it has been suggested that $\mathrm{Cd}$ is consumed during the northward transport of the CDW [Abouchami et al., 2011]. Although not as clearly as for $\mathrm{Zn}$, the increase of $\mathrm{Cd}$ at greatest depths also seem to be related to the presence of AABW, indicative of the importance of water masses defining the trace metal concentrations around Crozet and particularly in deep waters where biological activity is negligible.

3.2.5. Lead

[42] Dissolved $\mathrm{Pb}$ decreased with depth at M1 which is likely due to scavenging processes related to the higher export of particles in the bloom [Morris et al., 2007]. In contrast, concentrations at M3 and M2 were constant throughout most of the water column and only decreased at deeper depths (Figure 3).

[43] Dissolved $\mathrm{Pb}$ concentrations ranged from 6 to 22 pM (Figure 3) with lowest concentrations found in deep waters at M2 (Figure 3) probably related to older waters that suffered from scavenging over longer time scales such as $\mathrm{AABW}$, whereas highest concentrations were measured in the surface layer at M1. Our range for dissolved Pb concentrations is consistent with reported values of 11-21 pmol kg-1 [Ellwood, 2008] and 9-22 pM for the Australian PFZ (JARE-43 cruise, Lai et al. [2008]). Lai et al. [2008] also provided values as high as $165 \mathrm{pM}$ associated to episodic dust events during the KH-01-03 cruise. Other studies in the Southern Ocean (Table 3) were also in agreement with these data.

[44] A north-south gradient was observed in surface waters with $\mathrm{M} 1$ showing $\mathrm{Pb}$ concentrations twice as high as for M3 and M2 (Figure 3). Because concentrations around Crozet were homogeneous throughout the water column or decreased with depth, upwelling could not explain such a surface maximum at M1. Given the anthropogenic nature of $\mathrm{Pb}$ and the remoteness of the sampling area, an atmospheric source seems the most likely explanation for such high surface values. Model estimations suggest little atmospheric input to the Southern Ocean [Jickells et al., 2005] and air parcel back trajectories indicated no contact with other land masses than Antarctica at least 5 days prior to the sampling [Planquette et al., 2007]. Nevertheless, it is possible that an air mass which has been in contact before with the African continent reached the Crozet region after the main nutrient drawdown, thus explaining lack of significant surface $\mathrm{Pb}$ removal. There is evidence of $\mathrm{Pb}$ enriched dust supply along $30^{\circ} \mathrm{S}$ in the southwestern Indian Ocean that was attributed to southerly and westerly air mass trajectories likely originating from South Africa [Witt et al.,
2006]. M3 and M2 were 260 and $475 \mathrm{~km}$ southeast of M1, possibly enough to explain such a north-south gradient with lower $\mathrm{Pb}$ concentrations in the south. Recently, Heimburger et al. [2013] reported daily deposition fluxes at Crozet Islands for several elements, including $\mathrm{Pb}$ (246 pmol $\mathrm{m}^{-2} \mathrm{~d}^{-1}$ ). Using a $\mathrm{Kz}$ of $11 \mathrm{~cm}^{2} \mathrm{~s}^{-1}$ [Charette et al., 2007] and a vertical $\mathrm{Pb}$ gradient of $4.6 \mathrm{pmol} \mathrm{m} \mathrm{m}^{-3} \mathrm{~m}^{-1}$, the vertical input of $\mathrm{Pb}$ at station M3 would account for 438 pmol $\mathrm{m}^{-2} \mathrm{~d}^{-1}$, which is in a similar order of magnitude than the atmospheric flux calculated by Heimburger et al. [2013].

\subsubsection{Aluminium}

[45] Dissolved Al concentrations at M2 were low (Figure 3 ) and ranged from 0.13 to $2.15 \mathrm{nM}$ which is in line with values reported (Table 3 ) for the Crozet Basin region [van Beusekom et al., 1997] and more recent data for the Southern Ocean [Middag et al., 2011a].

[46] In the upper $1000 \mathrm{~m}$, dissolved $\mathrm{Al}$ remained below $0.60 \mathrm{nM}$. Then $\mathrm{Al}$ concentrations increased with depth reaching maximum concentrations of $2.15 \mathrm{nM}$ at about 2000 $\mathrm{m}$ that coincided with a maximum in salinity associated to LCDW influenced by NADW. Higher Al concentrations within the LCDW due to mixing with NADW have been reported before in the PFZ of the Atlantic sector [Middag et al., 2011a] and in the S11 profile of van Beusekom et al. [1997].

[47] The lower Al concentration at about $3000 \mathrm{~m}$ could be either the source concentration of the AABW or, the consequence of removal by scavenging processes which often influence the fate of $\mathrm{Al}$ in the water column [Orians and Bruland, 1985], whereas the small increase observed at the greatest sampled depth possibly reflects the picking up of Al from contact with sediments. This sedimentary source likely originates from Del Caño Rise rather than from the Crozet Islands since site M2 is shown to have very low particulate Al inputs at least in the upper water column [Planquette et al., 2009]. Dissolved Al and Si were uncoupled and did now show a significant correlation $\left(r^{2}=0.36\right.$; $p<0.001)$ throughout the water column and in benthic waters, where Al showed a relative small increase compared to $\mathrm{Si}$, which is not what was observed by Middag et al. [2009]. This might be due to the fact that this station did not have enhanced biological activity, being in a HNLC zone.

\subsubsection{Manganese}

[48] Dissolved Mn concentrations to the south of the Crozet Islands (Site M2, Figure 3) were very low and varied from $0.64 \mathrm{nM}$ in the surface to $\sim 70 \mathrm{pM}$ at the deepest point which is consistent with other trace metal work in the Southern Ocean (Table 3). This station showed a typical oceanic profile, with high surface concentrations followed by scavenging with depth [Landing and Bruland, 1980]. Elevated surface concentrations probably show the combination of aeolian inputs [Landing and Bruland, 1980], also seen for $\mathrm{Al}$, but practically unnoticeable for $\mathrm{Pb}$ (at M2) and $\mathrm{Fe}$ [Planquette et al., 2007] and, the photo reduction of Mn oxides [Sunda and Huntsman, 1988, 1994; Sunda et al., 1983]. The low Mn concentrations below $100 \mathrm{~m}$ were likely linked to the sinking and scavenging of Mn oxides [Statham et al., 1998; Sunda and Huntsman, 1988; Sunda et al., 1983], particularly in older waters masses such as CDW and AABW that have been influenced by particle 
flux and Mn oxidation over longer time scales. Middag et al. [2011b], report a similar general pattern with a surface maximum of around $\sim 0.4 \mathrm{nmol} \mathrm{kg}{ }^{-1}$ rapidly decreasing to values below $0.15 \mathrm{nM}$ in the PFZ.

\section{Conclusions}

[49] Dissolved Ni, Zn, Co, Cd, Pb, Al, and Mn distributions were affected by biological uptake, scavenging processes, the Crozet Islands, and possible atmospheric inputs. These processes led to different biogeochemical regimes. The HNLC control zone to the south showed no apparent island influence and trace metal concentrations in the range of other areas of the Southern Ocean. Mixing of water masses of different age appear to influence the vertical distribution of the metals to the south and near Crozet Islands, particularly at intermediate and deep layers where biological activity is not significant. In the bloom area, significant surface depletion was found for $\mathrm{Cd}$ and to a less extent for $\mathrm{Ni}$ indicating the importance of biological processes such as the active uptake in their biogeochemical cycling. Concentrations of $\mathrm{Ni}$ in the bloom and concentrations of $\mathrm{Zn}$ around Crozet appear to be related to the cycling of $\mathrm{Si}$ and diatoms. Even though Crozet is truly remote, dissolved $\mathrm{Pb}, \mathrm{Al}$, and $\mathrm{Mn}$ results suggest that possible atmospheric inputs in surface waters could have led to small increases in trace metal concentrations especially to the north. $\mathrm{Zn}$ and $\mathrm{Cd}$ concentrations were significantly higher near the islands and could be that Crozet is acting as a source in a similar manner to Fe.

[50] Acknowledgments. We would like to thank the captain and crew of the RRS Discovery for their brilliant work at sea. Thanks as well to the scientific crew that provided the inorganic nutrient data. This cruise was the first of the CROZEX project which was a component of the British BICEP (Biophysical Interactions and Control of Export Production) program supported by NERC (Natural Environmental Research Council). We finally acknowledge Peter Croot and the anonymous reviewers for their very constructive comments on this manuscript.

\section{References}

Abollino, O., M. Aceto, S. Buoso, C. La Gioia, C. Sarzanini, and E. Mentasti (2004), Distribution of major, minor and trace elements in Antarctic offshore and coastal seawaters: Correlation among sites and variables by pattern recognition, Int. J. Environ. Anal. Chem., 84(6-7), 471-492.

Abouchami, W., S. J. G. Galer, H. J. W. de Baar, A. C. Alderkamp, R. Middag, P. Laan, H. Feldmann, and M. O. Andreae (2011), Modulation of the Southern Ocean cadmium isotope signature by ocean circulation and primary productivity, Earth Planet. Sci. Lett., 305(1-2), 83-91.

Agranoff, D., L. Collins, D. Kehres, T. Harrison, M. Maguire, and S. Krishna (2005), The Nramp orthologue of Cryptococcus neoformans is a $\mathrm{pH}$-dependent transporter of manganese, iron, cobalt and nickel, Biochem. J., 385, 225-232.

Anderson, R. F., S. Ali, L. I. Bradtmiller, S. H. H. Nielsen, M. Q. Fleisher, B. E. Anderson, and L. H. Burckle (2009), Wind-driven upwelling in the Southern Ocean and the Deglacial Rise in the atmospheric $\mathrm{CO}_{2}$, Science, 323(5920), 1443-1448.

Aparicio-Gonzalez, A., C. M. Duarte, and A. Tovar-Sanchez (2012), Trace metals in deep ocean waters: A review, J. Mar. Syst., 100, 26-33.

Bown, J., M. Boye, A. Baker, E. Duvieilbourg, F. Lacan, F. Le Moigne, S. Speich, and D. M. Nelson (2011), The biogeochemical cycle of dissolved cobalt in the Atlantic and the Southern Ocean south off the coast of South Africa, Mar. Chem., 126, 193-206.

Bown, J., M. Boye, P. Laan, A. R. Bowie, Y. H. Park, C. Jeandel, and D. M. Nelson (2012), Imprint of a dissolved cobalt basaltic source on the Kerguelen Plateau, Biogeosciences, 9(12), 5279-5290.

Boyd, P. W., et al. (2007), Mesoscale iron enrichment experiments 1993 2005: Synthesis and future directions, Science, 315(5812), 612-617.
Boye, M., B. D. Wake, P. Lopez Garcia, J. Bown, A. R. Baker, and E. P. Achterberg (2012), Distributions of dissolved trace metals (Cd, $\mathrm{Cu}, \mathrm{Mn}$, $\mathrm{Pb}, \mathrm{Ag})$ in the southeastern Atlantic and the Southern Ocean, Biogeosciences, 9(8), 3231-3246.

Bruland, K. W. (1989), Complexation of zinc by natural organic-ligands in the Central North Pacific, Limnol. Oceanogr., 34(2), 269-285.

Bruland, K. W. (1992), Complexation of cadmium by natural organicligands in the Central North Pacific, Limnol. Oceanogr., 37(5), 10081017

Bucciarelli, E., S. Blain, and P. Treguer (2001), Iron and manganese in the wake of the Kerguelen Islands (Southern Ocean), Mar. Chem., 73(1), 21-36.

Butler, E. C. V., J. E. O'Sullivan, R. J. Watson, A. R. Bowie, T. A. Remenyi, and D. Lannuzel (2013), Trace metals $\mathrm{Cd}, \mathrm{Co}, \mathrm{Cu}, \mathrm{Ni}$, and $\mathrm{Zn}$ in waters of the subantarctic and Polar Frontal Zones south of Tasmania during the "SAZ-Sense" project, Mar. Chem., 148, 63-76.

Charette, M. A., M. E. Gonneea, P. J. Morris, P. Statham, G. Fones, H. Planquette, I. Salter, and A. N. Garabato (2007), Radium isotopes as tracers of iron sources fueling a Southern Ocean phytoplankton bloom, Deep Sea Res., Part II, 54(18-20), 1989-1998.

Coale, K. H., and K. W. Bruland (1988), Copper complexation in the Northeast Pacific, Limnol. Oceanogr., 33(5), 1084-1101.

Coale, K. H., R. M. Gordon, and X. J. Wang (2005), The distribution and behavior of dissolved and particulate iron and zinc in the Ross Sea and Antarctic circumpolar current along 170 degrees W, Deep Sea Res., Part I, 52(2), 295-318.

Corami, F., G. Capodaglio, C. Turetta, F. Soggia, E. Magi, and M. Grotti (2005), Summer distribution of trace metals in the western sector of the Ross Sea, Antarctica, J. Environ. Monit., 7(12), 1256-1264.

Croot, P. L., O. Baars, and P. Streu (2011), The distribution of dissolved zinc in the Atlantic sector of the Southern Ocean, Deep Sea Res., Part II, 58(25-26), 2707-2719.

Cullen, J. T., Z. Chase, K. H. Coale, S. E. Fitzwater, and R. M. Sherrell (2003), Effect of iron limitation on the cadmium to phosphorus ratio of natural phytoplankton assemblages from the Southern Ocean, Limnol. Oceanogr., 48(3), 1079-1087.

Cuvelier, M. L., et al. (2010), Targeted metagenomics and ecology of globally important uncultured eukaryotic phytoplankton, Proc. Natl. Acad. Sci. U.S. A., 107(33), 14,679-14,684.

de Baar, H. J. W., P. M. Saager, R. F. Nolting, and J. Vandermeer (1994), Cadmium versus phosphate in the World Ocean, Mar. Chem., 46(3), 261-281.

de Baar, H. J. W., et al. (2005), Synthesis of iron fertilization experiments: From the iron age in the age of enlightenment, J. Geophys. Res., 110, C09S16, doi:10.1029/2004JC002601.

De La Rocha, C. L., D. A. Hutchins, M. A. Brzezinski, and Y. H. Zhang (2000), Effects of iron and zinc deficiency on elemental composition and silica production by diatoms, Mar. Ecol. Prog. Ser., 195, 71-79.

De Vries, T., and F. Primeau (2011), Dynamically and observationally constrained estimates of water-mass distributions and ages in the global ocean, J. Phys. Oceanogr., 41(12), 2381-2401.

Doi, T., H. Obata, and M. Maruo (2004), Shipboard analysis of picomolar levels of manganese in seawater by chelating resin concentration and chemiluminescence detection, Anal. Bioanal. Chem., 378(5), 12881293

Ellwood, M. J. (2008), Wintertime trace metal ( $\mathrm{Zn}, \mathrm{Cu}, \mathrm{Ni}, \mathrm{Cd}, \mathrm{Pb}$ and $\mathrm{Co}$ ) and nutrient distributions in the Subantarctic Zone between 40-52 degrees S; 155-160 degrees E, Mar. Chem., 112(1-2), 107-117, doi:10.1016/ j.marchem.2008.07.008.

Ellwood, M. J., and C. M. G. van den Berg (2000), Zinc speciation in the Northeastern Atlantic Ocean, Mar. Chem., 68, 295-306.

Ellwood, M. J., and C. M. G. van den Berg (2001), Determination of organic complexation of cobalt in seawater by cathodic stripping voltammetry, Mar. Chem., 75(1-2), 33-47.

Ellwood, M. J., C. M. G. van den Berg, M. Boye, M. Veldhuis, J. T. M. de Jong, H. J. W. de Baar, P. L. Croot, and G. Kattner (2005), Organic complexation of cobalt across the Antarctic Polar Front in the Southern Ocean, Mar. Freshwater Res., 56(8), 1069-1075.

Fitzwater, S. E., K. S. Johnson, R. M. Gordon, K. H. Coale, and W. O. Smith (2000), Trace metal concentrations in the Ross Sea and their relationship with nutrients and phytoplankton growth, Deep Sea Res., Part II, 47(15-16), 3159-3179.

Frew, R., A. Bowie, P. Croot, and S. Pickmere (2001), Macronutrient and trace-metal geochemistry of an in situ iron-induced Southern Ocean bloom, Deep Sea Res., Part II, 48(11-12), 2467-2481. 


\section{CASTRILLEJO ET AL.: DISSOLVED TRACE METALS, CROZET ISLANDS}

Gosnell, K. J., W. M. Landing, and A. Milne (2012), Fluorometric detection of total dissolved zinc in the southern Indian Ocean, Mar. Chem. $132,68-76$.

Grotti, M., F. Soggia, M. L. Abelmoschi, P. Rivaro, E. Magi, and R. Frache (2001), Temporal distribution of trace metals in Antarctic coastal waters, Mar. Chem., 76(3), 189-209.

Heimburger, A., R. Losno, S. Triquet, and E. B. Nguyen (2013), Atmospheric deposition fluxes of 26 elements over the Southern Indian Ocean Time series on Kerguelen and Crozet Islands, Global Biogeochem Cycles, 27, 440-449, doi:10.1002/gbc.20043.

Hydes, D. J., and P. S. Liss (1976), Fluorometric method for determination of low concentrations of dissolved aluminium in natural waters, Analyst, 101(1209), 922-931.

Jickells, T. D., et al. (2005), Global iron connections between desert dust, ocean biogeochemistry, and climate, Science, 308(5718), 67-71.

Kinugasa, M., T. Ishita, Y. Sohrin, K. Okamura, S. Takeda, J. Nishioka, and A. Tsuda (2005), Dynamics of trace metals during the subarctic Pacific iron experiment for ecosystem dynamics study (SEEDS2001), Prog. Oceanogr., 64(2-4), 129-147.

Kustka, A. B., A. E. Allen, and F. M. M. Morel (2007), Sequence analysis and transcriptional regulation of iron acquisition genes in two marine diatoms, J. Phycol., 43(4), 715-729.

Lai, X., K. Norisuye, M. Mikata, T. Minami, A. R. Bowie, and Y. Sohrin (2008), Spatial and temporal distribution of $\mathrm{Fe}, \mathrm{Ni}, \mathrm{Cu}$ and $\mathrm{Pb}$ along 140 degrees E in the Southern Ocean during austral summer 2001/02, Mar Chem., 111(3-4), 171-183.

Landing, W. M., and K. W. Bruland (1980), Manganese in the North Pacific, Earth Planet. Sci. Lett., 49(1), 45-56.

Lane, T. W., and F. M. M. Morel (2000), A biological function for cadmium in marine diatoms, PNAS, 97, 4627-4631.

Lohan, M. C., P. J. Statham, and D. W. Crawford (2002), Total dissolved zinc in the upper water column of the subarctic North East Pacific, Deep Sea Res., Part II, 49(24-25), 5793-5808.

Löscher, B. M. (1999), Relationships among Ni, Cu, Zn, and major nutrients in the Southern Ocean, Mar. Chem., 67(1-2), 67-102.

Löscher, B. M., J. T. M. de Jong, and H. J. W. de Baar (1998), The distribution and preferential biological uptake of cadmium at 6 degrees $\mathrm{W}$ in the Southern Ocean, Mar. Chem., 62(3-4), 259-286.

Mann, E. L., N. Ahlgren, J. W. Moffett, and S. W. Chisholm (2002), Copper toxicity and cyanobacteria ecology in the Sargasso Sea, Limnol. Oceanogr., 47(4), 976-988.

Mantyla, A. W., and J. L. Reid (1983), Abyssal characteristics of the world ocean waters, Deep Sea Res., Part A, 30(8), 805-833.

Marinov, I., A. Gnanadesikan, J. R. Toggweiler, and J. L. Sarmiento (2006), The Southern Ocean biogeochemical divide, Nature, 441(7096), 964-967.

Martin, J. H., R. M. Gordon, and S. E. Fitzwater (1990), Iron in Antarctic waters, Nature, 345(6271), 156-158.

Middag, R., H. J. W. de Baar, Laan, P., Bakker, K. (2009), Dissolved aluminium and the silicon cycle in the Arctic Ocean, Mar. Chem., 115 176-195.

Middag, R., C. van Slooten, H. J. W. de Baar, and P. Laan (2011a), Dissolved aluminium in the Southern Ocean, Deep Sea Res., Part II, $58(25-$ 26), 2647-2660

Middag, R., H. J. W. de Baar, P. Laan, P. H. Cai, and J. C. van Oijen (2011b), Dissolved manganese in the Atlantic sector of the Southern Ocean, Deep Sea Res., Part II, 58(25-26), 2661-2677.

Middag, R., H. J. W. de Baar, P. Laan, and O. Huhn (2012), The effects of continental margins and water mass circulation on the distribution of dissolved aluminum and manganese in Drake Passage, J. Geophys. Res., 117, C01019, doi:10.1029/2011JC007434.

Milne, A., W. Landing, M. Bizimis, and P. Morton (2010), Determination of $\mathrm{Mn}, \mathrm{Fe}, \mathrm{Co}, \mathrm{Ni}, \mathrm{Cu}, \mathrm{Zn}, \mathrm{Cd}$ and $\mathrm{Pb}$ in seawater using high resolution magnetic sector inductively coupled mass spectrometry (HR-ICP-MS), Anal. Chim. Acta, 665(2), 200-207.

Moore, C. M., A. E. Hickman, A. J. Poulton, S. Seeyave, and M. I. Lucas (2007), Iron-light interactions during the CROZet natural iron bloom and EXport experiment (CROZEX) II: Taxonomic responses and elemental stoichiometry, Deep Sea Res., Part II, 54(18-20), 2066-2084.

Moran, S. B., R. M. Moore, and S. Westerlund (1992), Dissolved aluminium in the Weddell Sea, Deep Sea Res., Part A, 39(3-4A), 537-547.

Morel, F. M. M., and N. M. Price (2003), The biogeochemical cycles of trace metals in the oceans, Science, 300(5621), 944-947.

Morel, F. M. M., J. R. Reinfelder, S. B. Roberts, C. P. Chamberlain, J. G. Lee, and D. Yee (1994), Zinc and carbon co-limitation of marinephytoplankton, Nature, 369(6483), 740-742.
Morley, N. H., P. J. Statham, and J. D. Burton (1993), Dissolved trace metals in the southwestern Indian Ocean, Deep Sea Res., Part I, 40(5), 1043-1062.

Morris, P. J., R. Sanders, R. Turnewitsch, and S. Thomalla (2007), Th-234derived particulate organic carbon export from an island-induced phytoplankton bloom in the Southern Ocean, Deep Sea Res., Part II, 54(1820), 2208-2232.

Nakatsuka, S., K. Okamura, S. Takeda, J. Nishioka, M. L. Firdaus, K. Norisuye, and Y. Sohrin (2009), Behaviors of dissolved and particulate Co, Ni, $\mathrm{Cu}, \mathrm{Zn}, \mathrm{Cd}$ and $\mathrm{Pb}$ during a mesoscale Fe-enrichment experiment (SEEDS II) in the western North Pacific, Deep Sea Res., Part II, 56(26), 2822-2838

Nolting, R. F., and H. J. W. Debaar (1994), Behavior of nickel, copper, zinc and cadmium in the upper $300 \mathrm{~m}$ of a transect in the Southern-Ocean (57-degrees-62-degrees-S, 49-degrees-W), Mar. Chem., 45(3), 225-242.

Nolting, R. F., H. J. W. Debaar, A. J. Vanbennekom, and A. Masson (1991), Cadmium, copper and iron in the Scotia Sea, Weddell Sea and Weddell-Scotia confluence (Antarctica), Mar. Chem., 35(1-4), 219243.

Oliveira, L., and N. J. Antia (1984), Evidence of nickel ion requirement for autotrophic growth of a marine diatom with urea serving as nitrogen source, Br. Phycological J., 19(2), 125-134.

Orians, K. J., and K. W. Bruland (1985), Dissolved aluminium in the Central North Pacific, Nature, 316(6027), 427-429.

Park, Y. H., L. Gamberoni, and E. Charriaud (1993), Frontal structure, water masses, and circulation in the Crozet Basin, J. Geophys. Res., 98, $12,361-12,385$

Planquette, H., et al. (2007), Dissolved iron in the vicinity of the Crozet Islands, Southern Ocean, Deep Sea Res., Part II, 54(18-20), 19992019.

Planquette, H., G. R. Fones, P. J. Statham, and P. J. Morris (2009), Origin of iron and aluminium in large particles $(>53 \mathrm{mu} \mathrm{m})$ in the Crozet region, Southern Ocean, Mar. Chem., 115(1-2), 31-42.

Pollard, R. T., and J. F. Read (2001), Circulation pathways and transports of the Southern Ocean in the vicinity of the Southwest Indian Ridge, J. Geophys. Res., 106, 2881-2898.

Pollard, R. T., M. I. Lucas, and J. F. Read (2002), Physical controls on biogeochemical zonation in the Southern Ocean, Deep Sea Res., Part II, 49(16), 3289-3305

Pollard, R. T., H. J. Venables, J. F. Read, and J. T. Allen (2007a), Largescale circulation around the Crozet Plateau controls an annual phytoplankton bloom in the Crozet Basin, Deep Sea Res., Part II, 54(18-20), 1915-1929.

Pollard, R. T., R. Sanders, M. Lucas, and P. Statham (2007b), The Crozet natural iron bloom and export experiment (CROZEX), Deep Sea Res., Part II, 54(18-20), 1905-1914.

Pollard, R. T., et al. (2009), Southern Ocean deep-water carbon export enhanced by natural iron fertilization, Nature, 457(7229), 577-581.

Poulton, A. J., C. M. Moore, S. Seeyave, M. I. Lucas, S. Fielding, and P. Ward (2007), Phytoplankton community composition around the Crozet Plateau, with emphasis on diatoms and Phaeocystis, Deep Sea Res., Part II, 54(18-20), 2085-2105.

Price, N. M., and F. M. M. Morel (1991), Colimitation of phytoplankton growth by nickel and nitrogen, Limnol. Oceanogr., 36(6), 1071-1077.

Read, J. F., R. T. Pollard, and J. T. Allen (2007), Sub-mesoscale structure and the development of an eddy in the Subantarctic Front north of the Crozet Islands, Deep Sea Res., Part II, 54(18-20), 1930-1948.

Resing, J. A., and C. I. Measures (1994), Fluorometric determination of Al in seawater by flow-injection analysis with in-line preconcentration, Anal. Chem., 66(22), 4105-4111.

Rueter, J. G., and F. M. M. Morel (1981), The interaction between zinc defficiency and copper toxicity as it affects the silicic acid uptake mechanisms in Thalassiosira pseudonana, Limnol. Oceanogr., 26(1), 67-73.

Saito, M. A., J. W. Moffett, and G. DiTullio (2004), Cobalt and nickel in the Peru upwelling region: A major flux of labile cobalt utilized as a micronutrient, Global Biogeochem. Cycles, 18, GB4030, doi:10.1029/ 2003 GB002216.

Saito, M. A., T. J. Goepfert, A. E. Noble, E. M. Bertrand, P. N. Sedwick, and G. R. DiTullio (2010), A seasonal study of dissolved cobalt in the Ross Sea, Antarctica: micronutrient behavior, absence of scavenging, and relationships with $\mathrm{Zn}, \mathrm{Cd}$, and P, Biogeosciences, 7(12), 40594082

Salter, I., R. S. Lampitt, R. Sanders, A. Poulton, A. E. S. Kemp, B. Boorman, K. Saw, and R. Pearce (2007), Estimating carbon, silica and diatom 


\section{CASTRILLEJO ET AL.: DISSOLVED TRACE METALS, CROZET ISLANDS}

export from a naturally fertilized phytoplankton bloom in the Southern Ocean using PELAGRA: A novel drifting sediment trap, Deep Sea Res., Part II, 54(18-20), 2233-2259.

Sanders, R., and T. Jickells (2000), Total organic nutrients in Drake Passage, Deep Sea Res., Part I, 47(6), 997-1014.

Sanders, R., P. J. Morris, M. Stinchcombe, S. Seeyave, H. Venables, and M. Lucas (2007), New production and the f ratio around the Crozet Plateau in austral summer 2004-2005 diagnosed from seasonal changes in inorganic nutrient levels, Deep Sea Res., Part II, 54(18-20), 2191 2207.

Sanudo-Wilhelmy, S. A., K. A. Olsen, J. M. Scelfo, T. D. Foster, and A. R. Flegal (2002), Trace metal distributions off the Antarctic Peninsula in the Weddell Sea, Mar. Chem., 77(2-3), 157-170.

Sarmiento, J. L., T. M. C. Hughes, R. J. Stouffer, and S. Manabe (1998), Simulated response of the ocean carbon cycle to anthropogenic climate warming, Nature, 393(6682), 245-249.

Sedwick, P. N., P. R. Edwards, D. J. Mackey, F. B. Griffiths, and J. S. Parslow (1997), Iron and manganese in surface waters of the Australian subantarctic region, Deep Sea Res., Part I, 44(7), 1239-1253.

Sedwick, P. N., G. R. DiTullio, and D. J. Mackey (2000), Iron and manganese in the Ross Sea, Antarctica: Seasonal iron limitation in Antarctic shelf waters, J. Geophys. Res., 105, 11,321-11,336.

Sedwick, P. N., S. Blain, B. Queguiner, F. B. Griffiths, M. Fiala, E. Bucciarelli, and M. Denis (2002), Resource limitation of phytoplankton growth in the Crozet Basin, Subantarctic Southern Ocean, Deep Sea Res., Part II, 49(16), 3327-3349.

Seeyave, S., M. I. Lucas, C. M. Moore, and A. J. Poulton (2007), Phytoplankton productivity and community structure in the vicinity of the Crozet Plateau during austral summer 2004/2005, Deep Sea Res., Part II, 54(18-20), 2020-2044.

Shelley, R. U., B. Zachhuber, P. N. Sedwick, P. J. Worsfold, and M. C. Lohan (2010), Determination of total dissolved cobalt in UV-irradiated seawater using flow injection with chemiluminescence detection, Limnol. Oceanogr. Methods, 8, 352-362.

Statham, P. J., P. A. Yeats, and W. M. Landing (1998), Manganese in the eastern Atlantic Ocean: processes influencing deep and surface water distributions, Mar. Chem., 61(1-2), 55-68.

Sunda, W.G. (2012), Feedback interactions between trace metal nutrients and phytoplankton in the ocean, Frontiers Microbiol., 3, 1-22.
Sunda, W. G., and S. A. Huntsman (1988), Effect of sunlight on redox cycles of manganese in the Southwestern Sargasso Sea, Deep Sea Res., Part A, 35(8), 1297-1317.

Sunda, W. G., and S. A. Huntsman (1994), Photoreduction of manganese in seawater, Mar. Chem., 46(1-2), 133-152.

Sunda, W. G., S. A. Huntsman, and G. R. Harvey (1983), Photoreduction of manganese oxides in seawater and its geochemical and biological implications, Nature, 301(5897), 234-236.

Twining, B. S., S. B. Baines, and N. S. Fisher (2004), Element stoichiometries of individual plankton cells collected during the Southern Ocean Iron Experiment (SOFeX), Limnol. Oceanogr., 49(6), 2115-2128.

Twining, B. S., S. B. Baines, J. B. Bozard, S. Vogt, E. A. Walker, and D. M. Nelson (2011), Metal quotas of plankton in the equatorial Pacific Ocean, Deep Sea Res., Part II, 58, 325-341.

Twining, B. S., S. B. Baines, S. Vogt, and D. M. Nelson (2012), Role of diatoms in nickel biogeochemistry in the ocean, Global Biogeochem. Cycles, 26, GB4001, doi:10.1029/2011GB004233.

van Bennekom, A. J., A. G. J. Buma, and R. F. Nolting (1991), Dissolved aluminium in the Weddell-Scotia confluence and effect of Al on the dissolution kinetics of biogenic silica, Mar. Chem., 35(1-4), 423-434.

van Beusekom, J. E. E., A. J. van Bennekom, P. Treguer, and J. Morvan (1997), Aluminium and silicic acid in water and sediments of the Enderby and Crozet Basins, Deep Sea Res., Part II, 44(5), 987-1003.

Venables, H. J., and M. C. Moore (2010), Phytoplankton and light limitation in the Southern Ocean: Learning from high-nutrient, high-chlorophyll areas, J. Geophys. Res., 115, C02015, doi:10.1029/2009JC005361.

Venables, H. J., R. T. Pollard, and E. E. Popova (2007), Physical conditions controlling the development of a regular phytoplankton bloom north of the Crozet Plateau, Southern Ocean, Deep Sea Res., Part II, 54(18-20), 1949-1965

Westerlund, S., and P. Ohman (1991a), Iron in the water column of the Weddell Sea, Mar. Chem., 35(1-4), 199-217.

Westerlund, S., and P. Ohman (1991b), Cadmium, copper, cobalt, nickel, lead, and zinc in the water column of Weddel Sea, Antarctica, Geochim. Cosmochim. Acta, 55(8), 2127-2146.

Witt, M., A. R. Baker, and T. D. Jickells (2006), Atmospheric trace metals over the Atlantic and South Indian Oceans: Investigation of metal concentrations and lead isotope ratios in coastal and remote marine aerosols, Atmos. Environ., 40(28), 5435-5451. 